Станимир

Панајотов

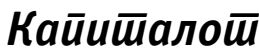 без вредност: советско-бугарската синтеза ${ }^{1}$}

Stanimir

Panayotov

\section{Capital without Value: The Soviet-Bulgarian Synthesis ${ }^{1}$}

\section{Биографска белешка}

Станимир Панајотов е докторант по компаративни родови студии на Централноевропскиот универзитет во Будимпешта.

Приемот на Марксовиот Каӣиӣал во Бугарија е особено комплициран предмет на истражување од две причини: 1) Треба да се дефинира многу концизно што точно беше „советскиот марксизам“ само во Бугарија, и до која мерка бил бугарскиот марксизам поразличен од советскиот марксизам? 2) Треба постојано да се следи границата помеѓу историјата на издавањето и партиските линии - во нашиот случај, владеењето на Бугарската комунистичка партија (БКП). Во овој напис се обидувам да се осврнам на

1 Написот е извадок од подолг ракопис. Делови од ракописот беа презентирани на Школата за политика и критика на 27 јуни 2017 г., во Охрид, Македонија, како и на 12 ноември 2017 г. во панелот „Дисеминацијата

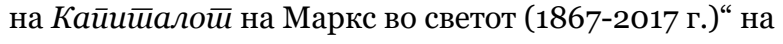
коференцијата Historical Materialism 2017, во Лондон. Други делови од овој ракопис за историјата и приемот на

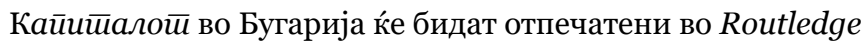
Handbook of Marx's Capital: A Global History of Translation, Dissemination and Reception, ed. by Marcello Musto and Babak Amini (London and New York: Routledge, 2018, forthcoming).

\section{Bionote}

Stanimir Panayotov is $\mathrm{PhD}$ Candidate in Comparative Gender Studies at the Central European University, Budapest.

The reception of Marx's Capital in Bulgaria is a particularly complicated subject of research for two reasons: 1) One needs to define very succinctly what exactly was "Soviet Marxism" in Bulgaria alone, and to what extent was Bulgarian Marxism different from Soviet Marxism? 2) One needs to constantly patrol the border between publishing history and party lines - in our case, the rule of the Bulgarian Communist Party (BCP). In this article I attempt to address both issues by looking at the publishing history and dissemination of Capital in Bulgaria and some examples of scientific contradictions

1 This article is an excerpt from a longer manuscript. Parts of the manuscript were presented at the School for Politics and Critique on June 27, 2017 in Ohrid, Macedonia, as well at the panel "The Dissemination of Marx's Capital in the World (1867-2017)" at the Historical Materialism 2017 conference in London, UK, on November 12, 2017. The remaining other parts of this manuscript, those on the history and reception of Capital in Bulgaria, will be published in Routledge Handbook of Marx's Capital: A Global History of Translation, Dissemination and Reception, ed. by Marcello Musto and Babak Amini (London and New York: Routledge, 2018, forthcoming). 
двете прашања преку разгледување на историјата на

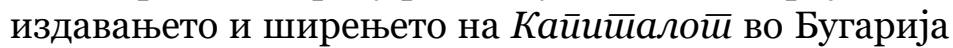
и некои примери на научни контрадикторности под практиката на официјално санкционираниот марксизам и научниот комунизам во комунистичка Бугарија. Тврдам дека, за да се разбере релаксираната ирелевантност на критиката на политичката економија во Бугарија, треба да се зборува повеќе за „советско-бугарска синтеза“ кога се зборува за „марксизмот“ што ја практикувала научнотехничката интелигенција под бугарското владеење во сателитски стил. Во тоа што следи, а) ќе се обидам во широки потези да објаснам некои аналитички осо-

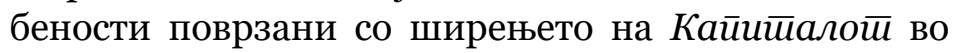
Бугарија $^{2}$, и тогаш б) ќе се обидам да го оправдам користењето на терминот „советско-бугарска (марксистичка) синтеза“.

\section{I.}

На 27 април, 1990 г., академскиот совет на Вишиот економски институт „Карл Маркс“ (ВЕИ) во Софија изгласа да се смени името во Универзитет за национална и светска економија (УНСЕ). Оваа промена на името не беше одраз само на концептуална декомунизација: по одлуката следеше брзо и буквално отстранување на статуата на Маркс од предната порта. Каменобелата биста на Маркс стоеше таму од 5 декември 1978 г. до 1990 г. ВЕИ го усвои патронското име на 24 март, 1953 г., а го смени во 1995 г. ${ }^{3}$.

2 Деталниот историски преглед ќе биде отпечатен во Musto and Amini, Routledge Handbook of Marx's Capital, видете белешка 1.

3 „Указ No. 89“, Известия, No. 23, 20 март 1953; „Становище на УНСС: За паметника на Карл Маркс“, Вестник на УНСC, No. 598, 28 јуни 2012, 5 . under the practices of officially sanctioned Marxism and scientific communism in communist Bulgaria. I claim that, in order to understand the relaxed irrelevance of the critique of political economy in Bulgaria, one should rather speak of a "Soviet-Bulgarian synthesis" when discussing the "Marxism" being practiced by the scientific-technical intelligentsia under the Bulgarian satellite-style rule. In what follows I will a) try and explain in broad strokes some analytical peculiarities related to the dissemination of Capital in Bulgaria, ${ }^{2}$ and will b) try and justify the use of the term "SovietBulgarian (Marxist) synthesis.”

\section{I.}

On April 27, 1990 the Academic Council of the Karl Marx Higher Economic Institute (HEI) in Sofia voted to change its name to University of National and World Economy (UNWE). This name change did not reflect merely a conceptual de-communization: the Council's decision was followed by the prompt and quite literal dismantling of Marx's statue at its front gates. Marx's stone-white bust stood there from December 5, 1978 until 1990, while HEI adopted his patron name on March 24, 1953 and lost it in $1995 .{ }^{3}$ In a surprising turn of events, on May $21^{\text {st, }}$ 2008, UNWE's Academic Council decided to reinstate the bust, which until then was kept in the university's depot. ${ }^{4}$ However, the bust no longer welcomed students, faculty and staff at the front gates: it was re-installed in the University's background spaces.

2 The detailed historical account will be published in Musto and Amini, Routledge Handbook of Marx's Capital, see note 1.

3 “Ukaz No. 89," Izvestiya, No. 23, March 20, 1953; "Stanovishte na UNSS: Za pametnika na Karl Marks," Vestnik na UNSS, No. 598, June 28, 2012, 5 .

4 See the short documentary Who Is that One on the Monument? (Sofia: The Marxist Club in UNWE, 2016), www.dokumentalni. $\operatorname{com} /$ ?p $=4117$. 
Во изненадувачки пресврт на настаните, на 21 мај, 2008 г., академскиот совет на УНСЕ одлучи да ја врати бистата која дотогаш се чувала во депото на универзитетот ${ }^{4}$. Меѓутоа, бистата веќе не ги дочекуваше студентите, професорите и персоналот на предната порта: таа беше преместена во задните простории на универзитетот.

Ја нудам оваа куса приказна за да ја изразам богатата

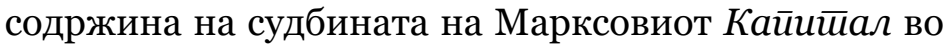
бугарскиот социо-економски пејзаж. Во неа има три клучни историски обележја: прво, ВЕИ го избра патронското име во 1953 г., годината кога почина Сталин, само 19 дена по неговата rigor mortis што предизвика трајни последици за прифаќањето на Маркс во целиот социјалистички блок и сателитските земји на Варшавскиот пакт, вклучувајќк ја и Бугарија; второ, камениот идеолошки и меморијален фетишизам на Маркс бил прекинат токму истата година кога БКП успеала да го отпечати 49-иот том на бугарското MEGA издание, не успеала да го издаде само последниот 50. том ${ }^{5}$; трето, повторното враќње на бистата било договорено во бурната 2008 г., година на последниот глобален финансиски неуспех на капитализмот. Во 2008 г., текстот на споменикот бил ажуриран, не само за да го историзира неговото присуство на универзитетот, туку и за да упати на анкетата на Би-Би-Си од 2008 г. „Најголем филозоф на нашето време, 20. век“, во која Маркс бил избран за победник. Конечно, не може да се пропушти йойосой на повторното поставување - задниот двор, йойос кој може просто да го опише интелектуално-

4 Видете го кусиот документарен филм Кој е на сйоменикой? (София: Марксистки клуб на УНСС, 2016), www.dokumentalni.com/?p=4117.

5 Томот бил подготвен за издавање, но никогаш не бил издаден. Професорот Петар-Емил Митев се обидел да го издаде, но издавачот кој првобитно покажал интерес, се повлекол.
Offering this brief story is a way to express a rich epitome of the fate of Marx's Capital in Bulgaria's socio-economic landscape. There are three crucial historical markers here: one, HEI chose its patron name in 1953, the year of Stalin's death, just 19 days after his rigor mortis that will have lasting consequences for Marx's reception in the entire Socialist Bloc and satellite Warsaw Pact countries, including Bulgaria; two, the stone-clad ideological and memorial fetishism of Marx was terminated in the exact same year that the BCP managed to publish Vol. 49 of the Bulgarian MEGA edition, falling short of publishing just the last Volume $50{ }^{5}$ three, the bust's re-installment was arranged in the tumultuous 2008, the year of the last global financial meltdown of capitalism. In 2008, the statue's inscriptions were even updated not only to historicize its presence at the University, but also to refer to BBC's 2008 In Our Times' Greatest Philosopher of XX Century poll, which picked Marx as the winner of history. Finally, one cannot miss the topos of that re-instatement - the back garden, a topos that can easily describe also the intellectual reception of Marx in Bulgaria post-1990, which I will not discuss here.

The aim here is not to prove a wholesale correlation between these events and historical markers. One should resist seeing 1953 as a "Bulgarian opening" to "critical Marxism." In fact, the reception of Capital and Marx's economic theories in Bulgaria remain enigmatically and paradoxically unoriginal, as destalinization did not bring about an intellectual thaw beyond the confines of historical materialism (hereafter histmat). As Dimitar Tsatsov claims, "[d]espite Stalin's death in 1953, the intellectual inertia towards ignoring humanist

5 The volume has been prepared for publication but was never published. An attempt has been made by Prof. Petar-Emil Mitev to publish it, but the publisher who initially revealed an interest withdrew. 
то прифаќање на Маркс во Бугарија по 1990-тите, за што нема да говорам тука.

Целта не е да се докаже големопродажна корелација помеѓу овие настани и историските маркери. Треба да се одолее да се гледа на 1953 г. како на „бугарско отворање“ кон „критичкиот марксизам“. Всуш-

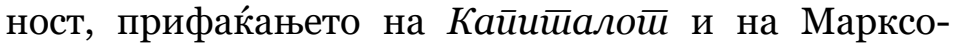
вите економски теории во Бугарија останува енигматично и парадоксално неооригинално, бидејќи десталинизацијата не довела до интелектуално одмрзнување кое ги надминало ограничувањата на историскиот материјализам. Како што тврди Димитар Цацов, „покрај смртта на Сталин во 1953 г., продолжува интелектуалната инерција кон игнорирањето на хуманистичката проблематика“6. Сепак, неочекуваната иронија на историјата е неодолива во случајов: додека е тешко да се докаже дека изборот на патронското име на ВЕИ имало врска со смртта на Сталин во 1953 г. ${ }^{7}$, во 1990 г. - годината во која во Бугарија се случија првите слободни избори на 10 и 17 ноември - несомнена е корелацијата меѓу отстранувањето на статуата и промената на режимот.

6 Димитьр Цацов, Догматици и ревизионисти в българския марксизъм (контекстът на производство на философски знания през 6о-те години на XX век) (София: Фабер, 2013), 25.

7 Има цврсти докази дека тогашниот претседавач на БКП, Валко Червенков (1900-1980), го следел ригорозно секој чекор на Сталин, видете John D. Bell, "Bulgaria: The Silent Partner," in East Central Europe: Yesterday, Today, Tomorrow, ed. by Milorad M. Drachkovitch (Stanford, California: Hoover Institution on War, Revolution, and Peace, 1981), 225, за тоа како во 1953 г. се гледало на воведувањето на Нов правец на Валко Червенов, воведувајќи „колективно водство“, начин на владеење преземен од неговиот наследник Антон Југов (1904-1991). Западните познавачи, како Бел, често го занемаруваат фактот дека владеењето на Червенков веќе било компромис со Сталиновите желби за целосна советска централизација на БКП. problematic continues." ${ }^{6}$ Yet the aleatory irony of history here is irresistible: while it is hard to prove that HEI's pick up of its patron name had to do with Stalin's death in $1953{ }^{7}$ in 1990 - the year which saw Bulgaria's first free elections on November 10 and 17 - the correlation between dismantling the statue and the regime change is unquestionable. The Council's 2008 decision, too, is not a matter of historical contingency: the UNWE is to this very day, despite the loss of Marxian patronship, an important (not to say the only) center of political economy in Bulgaria, where Marx's economic theories are actually taught. There is a good deal of Marxist economists still teaching there, and in 2011 the Department of Political Economy was re-established. ${ }^{8}$

This embodied brief account of Marx's fate in the front and the back of Bulgaria's foremost economic educational institution not only offers a seductive narrative on the politics of memory but also coincides with the publishing history of Marx's reception in general and Capital's reception in particular. Stalin's 1953 death opened the

6 Dimitar Tsatsov, Dogmatitsi i revizionisti v balgarskiya marksizam (kontekstat na proizvodstvo na filosofski znaniya prez 6o-te gofini na XX vek) (Sofia: Faber, 2013), 25.

7 There is strong evidence that the then BCP chairman Valko Chervenkov (1900-1980) followed Stalin rigorously in every step, see John D. Bell, “Bulgaria: The Silent Partner," in East Central Europe: Yesterday, Today, Tomorrow, ed. by Milorad M. Drachkovitch (Stanford, California: Hoover Institution on War, Revolution, and Peace, 1981), 225, concerning how 1953 saw the inauguration of a New Course by Valko Chervenkov introducing "collective leadership," a governance method taken up by his successor Anton Yugov (1904-1991). Western scholars, such as Bell, often neglect the fact that Chervenkov's rule was already a compromise with Stalin's wishes for a complete Soviet centralization of the BCP.

8 Some of the noteworthy names are Vasil Prodanov, Svetla Toshkova, Boyan Durankev. 
Одлуката на советот од 2008 г., исто така нема врска со историска случајност: УНСЕ до денешен ден, покрај губењето на Марксовото патронство, е важен (како и единствен) центар на политичка економија во Бугарија, каде што всушност се предаваат Марксовите економски теории. Има уште многу марксистички економисти што сѐ уште предаваат таму и во 2011 г., бил повторно воспоставен Одделот за политичка економија ${ }^{8}$.

Овој кус преглед на судбината на Маркс во предниот и во задниот дел на најголемата бугарска економска образовна институција не само што нуди заводлива нарација за политиката на меморијата, туку се поклопува и со историјата на издавањето на генералното прифаќање на Маркс, и конкретно, прифаќањето

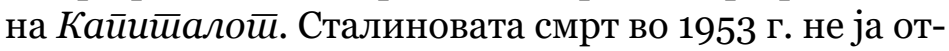
ворила вратата само за Маркс на предната порта на ВЕИ, туку и за десталинизираното и критичко издание на MEGA, кое веќе било во тек во Русија ${ }^{9}$. Било во тек и во Бугарија по 1948 г. Сепак, само по себе, тоа не придонело за порелаксирано студирање или интелектуален паралелизам меѓу партиите, масите и економијата во потрага по доверлива идеологија. Следи обид да се објаснат задушувачките услови за прифаќање на Маркс од БКП и нејзината научна инфраструктура.

8 Некои од поистакнатите имиња се Васил Проданов, Светла Тошкова, Бојан Дуранкев.

9 Во 1956 г. во Русија било издадено посебното издание на Маркс и Энгельс, Из ранних произведений (Москва: Государственное издательство политической литературы, 1956); видете го и индексот од 1967 г. од институтот МЕЛС што ја изнесува историјата на издавање на руски, клучна за студирањето на бугарските преводи на Маркс и Энгельс, Алфавитный указатель произведений, вошедших во второе издание сочинений К. Маркса и Ф. Энгельса (Москва: Издательство политической литературы, 1967). gate not only to Marx at the HEI's front doors but to a destalinized and critical edition of MEGA, which was already under way in Russia. ${ }^{9}$ It was also under way in Bulgaria after 1948. Yet in itself, this was not to bring a more relaxed study or intellectual parallelism between party, masses and economy in the pursuit of a reliable ideology. What follows is an attempt to explain the stifling conditions of the reception of Marx by the BCP and its scientific infrastructure.

\section{II.}

As will be demonstrated below, the mention of Russia/ USSR in Bulgaria's reception of Capital is unavoidable and is exactly what leads us towards the term "SovietBulgarian synthesis": the Bulgarian post-1948 MEGA edition, which hosts Capital, Vols. 1-4, is translated from and follows the Russian MEGA translations. ${ }^{10}$ Unsurprisingly, the Russian influence comes from one of the founders of the first socialist party in political history - Dimitar Blagoev (1856-1924), a Bulgarian who lived in Petersburg until 1885 and who then was extradited to his homeland, and who became the first translator of Capital in Bulgarian in its entirety. ${ }^{11}$ It is thanks to this episode and Blagoev's appearance on the radar of the

91956 saw the publishing in Russia of the specialized edition of Marx and Engels, Iz rannyikh proizvedenii (Moscow:

Gosudarstvennoe izdatelstvo politicheskoy literaturyi, 1956); see also the 1967 index by the MELS Institute which provides the publishing history in Russian, crucial for the study of Bulgarian Marx and Engels translations: Alfavitnyi ukazatel proizvedenii, voshedshih vo vtoroe izdanie sochinenii $K$. Marksa i F. Engelsa (Moscow: Izdatelstvo politicheskoy literaturyi, 1967).

10 The complete reconstruction of this story will be published in Musto and Amini, see note 1.

11 "Dimitar Blagoev," in Balgarska kniga. Entsiklopediya, ed. by Ani Gergova (Sofia: Pensoft, 2004), 78. 
II.

Како што ќе биде прикажано подолу, спомнувањето на Русија/СCCP во бугарското прифаќање на

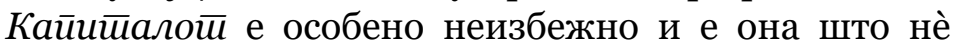
води кон терминот „советско-бугарска синтеза“: бугарската едиција на MEGA после 1948 г., која ги сод-

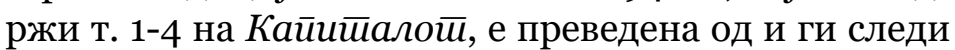
руските преводи на MEGA $^{10}$. Незачудувачки, руското влијание доаѓа од еден од основачите на првата социјалистичка партија во политичката историја Димитар Благоев (1856-1924), Бугарин кој живеел во Петроград до 1885 г. и кој потоа бил екстрадиран во својата татковина, и кој станал првиот преведувач на

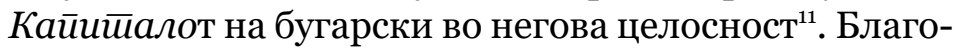
дарение на оваа епизода и на појавувањето на Благоев на радарот на царистичката полиција прифаќањето

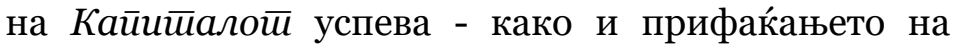
марксизмот во Бугарија. Индикативно е што за помалку од два месеца по поставувањето на бистата на Маркс на ВЕИ во 1953 г., 7 мај 1953 г., исто така била отворена спомен-куќата на Благоев во Софија.

Враќањето на Благоев во Бугарија го навело да го популаризира делото на Маркс и да креира бугарска марксистичка историографија. Во 1885 г., почнал да го издава списанието Съвременний показател ${ }^{12}$,

10 Целосната реконструкција на оваа приказна ќе биде објавена во Musto and Amini, повторно, видете белешка 1.

11 „Димитьр Благоев“, во Българска книга. Енциклопедия, съст. Ани Гергова (София: Пенсофт, 2004), 78.

12 Emilia Mineva, "On the Reception of Marxism in Bulgaria," translated from the Bulgarian by Regina Raycheva, Studies in East European Thought, Vol. 53, No. 1/2 (June 2001), 72 n.11. Во претходната забелешка, Минева ги наведува првите спомнувања за Маркс и Енгелс (вклучувајќи го обраќањето на Енгелс до Крастјо Раковски [1873-1942]), истото подетално го прави Marin Pundeff, "Marxism in Bulgaria before 1891," Slavic Review, Vol. 30, No. 3 (September tsarist police that the reception of Capital kicked off, so didthe reception of Marxism in Bulgaria. Significantly, in less than two months after the 1953 installment of Marx's bust in HEI, on May $7^{\text {th }}, 1953$ Blagoev's house museum was opened in Sofia, too.

Blagoev's return to Bulgaria led him to popularize Marx's work and in effect to create Bulgarian Marxist historiography. In 1885, he began publishing the journal Savremennii pokazatel, ${ }^{12}$ and in 1897 he established Novo vreme, titled after the German Die Neue Zeit, of which he was the editor-in-chief until 1923, when the journal ceased to exist, and which was relaunched again in 1947. This first decade after Bulgaria's liberation from the Ottoman empire in 1878/9 saw also the first steps towards the development of a distinct Bulgarian class consciousness in what scholars have called "party without proletariat." ${ }^{13}$ Despite the catastrophic historiographical thesis prevalent in Bulgaria's early communist period, ${ }^{14}$

12 Emilia Mineva, "On the Reception of Marxism in Bulgaria," translated from the Bulgarian by Regina Raycheva, Studies in East European Thought, Vol. 53, No. 1/2 (June 2001), 72 n.11. In the preceding note Mineva lists the first mentions of Marx and Engels (including Engels' address to Krastyo Rakovski [1873-1942]), as does in more thorough details Marin Pundeff, "Marxism in Bulgaria before 1891," Slavic Review, Vol. 30, No. 3 (September 1971), 524-5, with notes. However, these mentions do not constitute anything beyond an ideatic striving towards political consolidation often confused with ideals of national liberation and post-liberation Revival.

13 See Boris Popivanov, Changing Images of the Left in Bulgaria: An Old-and-New Divide? (New York: ibidem Press, 2015), 57 ff., who discusses Joseph Rothschield's analysis; but consider Pundeff's comment that "[a]rticulate political radicalism among Bulgarians before 1878 was represented only in their colonies abroad," Pundeff, "Marxism in Bulgaria before 1891," 526 , meaning the Bulgarian inteligenti studying abroad.

14 This thesis, which propagates that all Islamization was forced, was gradually nurtured in the theoretical organ of history from Bulgarian Academy of Sciences' (hereafter BAS) Institute of 
и во 1897 г. го основал списанието Ново време, наречено според германскиот Die Neue Zeit, каде што бил главен уредник до 1923 г., кога престанало да постои списанието. Повторно било лансирано во 1947 г. Во оваа прва декада по бугарското ослободување од отоманската империја во 1878/1879 г. се случиле и првите чекори кон развој на издвоена бугарска класна свест за она што познавачите го нарекувале „партија без пролетаријат“"13. Покрај катастрофалната историографска теза која преовладувала во бугарскиот ранокомунистички период ${ }^{14}$, која претпоставува дека Отоманите ја назадиле социокултурната мобилизација, реалистично е да се тврди дека уло-

1971), 524-5, со забелешки. Сепак, овие спомнувања не претставуваат ништо повеќе од идејното тежнеење кон политичко консолидирање што често се меша со идеалите на националното ослободување и обновата по ослободувањето.

13 Видете Boris Popivanov, Changing Images of the Left in Bulgaria: An Old-and-New Divide? (New York: ibidem Press, 2015), 57 ff., кој расправа за анализата на Џозеф Ротшилд; но земете го предвид коментарот на Пундеф дека „изразениот политички радикализам меѓу Бугарите пред 1878 г. бил претставуван само во нивните колонии во странство“, Pundeff, “Marxism in Bulgaria before 1891," 526,

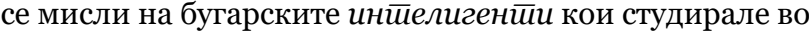
странство.

14 Оваа теза која пропагира дека сета исламизација била насилна, постепено била негувана во теоретскиот орган на историјата на Институт за историја во Бугарската академија на науките (понатаму во текстот БАН) Исторически преглед, на чело со Александар Бурмов (1911-1965), и подоцна е најдобро негувана од Веселин Хаџиниколов (1917-2003), Христо Христов (1915-1992), и Христо Гандев (1907-1987); за критичка анализа на тезата, видете Rossitsa Gradeva, "Conversion to Islam in Bulgarian Historiography: An Overview," in Religion, Ethnicity and Contested Nationhood in the Former Ottoman Space, ed. by Jørgen Nielsen (Leiden: Brill, 2012), 173-87. which posits that the Ottomans retarded socio-cultural mobilization, it is realistic to claim that Bulgaria's role in the first wave of socialist political mobilization toying with Marx's ideas was in line with the historical developments immediately after the liberation. But with the proviso that such immediacy was already mediated by the Russian literary influence brought by Blagoev.

There are two major and full translations by Blagoev and Bakalov. I will divide the publishing history of Capital here in two sub-stages that fall under the general period 1886-1944: 1) the legal period of the BCP, 1891-1923 (marked by the so-called September Uprising), and 2) the illegal period of BCP, 1923-1944 (i.e., until the seizure of power on September 9, 1944). Both of these translations are before the illegal period.

Blagoev was versed in several languages and could offer, though initially in part, a direct translation to the avid audience awaiting Capital. His 1909 translation was the first full translation of Capital, Vol. 1 in Bulgarian, translated from the German. The publisher is The Party's Socialist Bookshop and Printshop, which in 1909 stands for Bulgarian Workers' Social Democratic Party - Narrow Socialists, ${ }^{15}$ and was published in Sofia,

history - Istoricheski pregled, headed by Alexander Burmov (1911-1965), and later on is best articulated by Vesselin Hadzhinikolov (1917-2003), Khristo Khristov (1915-1992), and Khristo Gandev (1907-1987); for a critical analysis of the thesis, see Rossitsa Gradeva, "Conversion to Islam in Bulgarian Historiography: An Overview," in Religion, Ethnicity and Contested Nationhood in the Former Ottoman Space, ed. by Jørgen Nielsen (Leiden: Brill, 2012), 173-87.

15 In 1903, a decisive split happened in what was already a Blagoev-led compromise, i.e., The Bulgarian Workers' Social Democratic Party (Balgarska rabotnicheska sotsialdemokraticheska partiya; BRSDP) - the split between so-called broad and narrow socialists. The "broads" identified themselves with class collaboration and Bernsteinianism, 
гата на Бугарија во првиот бран на социјалистичкополитичката мобилизација која си играла со идеите на Маркс била во согласност со историските настани веднаш по ослободувањето но, сепак, со резерва дека таквата непосредност веќе била посредувана од руското литерарно влијание донесено од Благоев.

Има два поголеми и целосни превода на Благоев и на Бакалов. Ке ја поделам историјата на издавање на

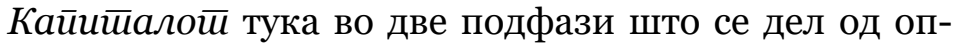
штиот период 1886-1944 г.: 1) легалниот период на БКП (обележана со таканареченото Септемвриско востание), и 2) нелегалниот период на БКП, 19231944 г. (т.е. до одземањето на сила на 9 септември, 1944 г.) И двата овие превода се пред незаконскиот период.

Благоев зборувал неколку јазици и можел да ѝ понуди, иако прво само делумно, директен превод на

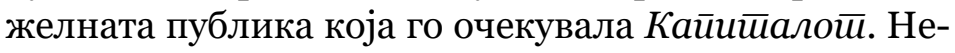
говиот превод од 1909 г. бил првиот целосен превод

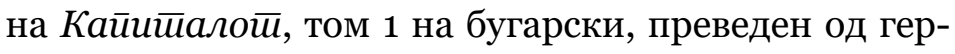
мански, издаден од Социјалистичката книжарница и печатница на партијата, која во 1909 г. ја поддржувала Бугарската работничка социјалдемократска партија - тесни социјалисти ${ }^{15}$, во Софија, новата престолнина на Бугарија. Наводно, изданието било отпечатено во 1910 г. (така е наведено на страницата на импресумот), но на насловната страница пишува 1909 г. Не можев да го докажам тоа, но или стану-

15 Во 1903 г., дошло до раскин во тоа што веќе било компромис воден од Благоев, т.е. во Бугарската работничка социјалдемократска партија (БРСДП) - раскинот помеѓу таканаречените широки и тесни социјалисти. „Широките“ се идентификувале себеси со класната соработка и Бернштајнизмот, додека „тесните“ останале на револуционерната патека и одбиле соработка. За тесните, понатаму во текстот ќе ја користам кратенката ТC, а за широките, ќе користам ШС.
Bulgaria's new capitol. Allegedly, the publication was printed in 1910 (the impressum page states so), but the title page is credited to 1909. I was not able to prove this, but this is either a typo (unlikely) or was Blagoev's way to acquire primacy over the other translation from 1910, that of Georgi Bakalov, of which he should have known and to which I now turn.

Georgi Bakalov published his translation, again from the German, in his hometown Stara Zagora. The publisher was The Liberal Club, which is a printshop rather than a publisher proper, and which helped dispersing the ideas of broad socialists, and later on hosting debates between the two factions in the journal Borba (published intermittently after 1913 in Sofia). ${ }^{16}$ He was also a member of Bulgarian Social Democratic Party as of 1891 and, likely much similar to many of the early Bulgarian socialists, was active in education and socalled uchitelsko delo (teachers' affairs). In 1891-93 he studied in Geneva and quickly befriended Plekhanov, whom he translated in the 1890s. ${ }^{17}$ In 1903-5 Bakalov was in the vanguard of the NS line. After 1905, he joined the anarcho-liberals' faction and moved on decidedly to the side of Blagoev's rivals, the BS, also known as obshtodeltsi (commoners).

while the "narrows" kept on the revolutionist path and refused collaborationism. For the narrows, I will use the abbreviation NS, and for the broads, I will use BS hereafter.

16 By "liberal" one should read "national-liberal"; this naming is also a reflection of the relations between Bakalov and Stefan Stambolov (1854-1895) and in general the closer ties developed after 1903/1923 between broad socialists, (national-)liberals and agrarian radicals.

17 Pundeff, "Marxism in Bulgaria before 1891," 548 n.86; Augusta Dimou, Entangled Paths Towards Modernity. Contextualizing Socialism and Nationalism in the Balkans (Budapest and New York: Central European University Press, 2009), 21. 
ва збор за печатна грешка (што е неверојатно) или Благоев на тој начин се обидел да биде пред другиот превод од 1910 г., тој на Ѓорѓи Бакалов, за кој тој би требало да знае и на кој се осврнувам сега.

Ѓрѓ́ Бакалов го објавил својот превод, повторно од германски јазик, во својот роден град Стара Загора. Издавачот сега е Либералниот клуб, повеќе печатница отколку издавачка куќа, кој помогнал да се прошират идеите на широките социјалисти, а подоцна бил домаќин на дебатите помеѓу двете фракции во списанието Борба (издавано со прекини по 1913 г. во Софија) ${ }^{16}$. Бил член и на Бугарската социјалдемократска партија од 1891 г. и, како што било нормално за раните бугарски социјалисти, бил активен во образованието и таканареченото учииелско gело. Во 1891-3 г. студирал во Женева и брзо се спријателил со Плеханов, кој го преведувал во 1890-тите ${ }^{17}$. Во 1903-5 г., Бакалов бил во авангардата на ТС. По 1905 г., ѝ се приклучил на фракцијата на анархолибералите и одлучно се префрлил на страната на ривалите на Благоев, ШС, исто така познати како общоделци.

Потеклото на разидувањата во бугарскиот марксизам се сведува на разделот меѓу ТС и ШС кој до 1909-10 г. веќе дефинирал две паралелни креда на социјализмот, а со тоа и два целосни превода на

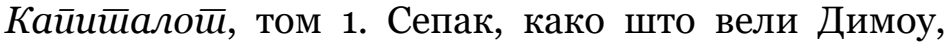

16 Под „либерали“ треба да се подразбере „националлиберали“; овој назив е исто така одраз на односите помеѓу Бакалов и Стефан Стамболов (1854-1895) и општо, поблиските врски развиени по 1903/1923 г. помеѓу широките социјалисти, (национал-)либерали и аграрски радикали. Pundeff, "Marxism in Bulgaria before 1891," 548 n.86; Augusta Dimou, Entangled Paths Towards Modernity. Contextualizing Socialism and Nationalism in the Balkans (Budapest and New York: Central European University Press, 2009), 21.
The genesis of differentiations inside Bulgarian Marxism comes down to the NS-BS split which by 1909/10 had already defined two parallel credos of socialism and two full translations of Capital, Vol. 1 along with that. However, as Dimou says, "[t] $\mathrm{t}$ he debate between the two factions was not about Marxism versus non-Marxism, but rather about the appropriate understanding and application of Marxist principles in Bulgarian society."18 By all means the division stemming from BRSDP debates and clashes until 1903 has had the consequences of appropriating an ideological attachment to Marx's Capital, which later in 1919 will help Bulgarian narrow socialists to evolve in their own identity from "socialdemocrats" and "socialists" to "communists."

In the illegal BCP period between 1923-44, the republications of both Blagoev's and Bakalov's translations appeared, and they each received one new edition, in two subsequent years (1930/31), both edited by Todor Pavlov. In this period, one can already see the consequences of political prosecution stemming from a sound identification with and political work on Marxism (consider that Todor Pavlov's edition of Bakalov's translation is credited to "Zh. Ivanov" Bakalov's pseudonym, ${ }^{19}$ and that Blagoev very early on have used pseudonyms, too, such as "Zheliazkov"). Most important, this period is marked by the arrival of Todor Pavlov (1890-1977) on the scene of Bulgarian philosophy and Marxism. In 1919 he joined Blagoev's the newly split off communist party at the time, by way of its joining the Third International. ${ }^{20}$ In this

18 Dimou, "Entangled Paths," 174.

19 On pseudonyms among Bulgarian socialists, see Pundeff, "Marxism in Bulgaria before 1891," 535-36 n.46.

20 "Bulgarian Communist Party (BCP)," in Historical Dictionary of Marxism, $2^{\text {nd }}$ edition, ed. by Elliott Johnson, David Walker, and Daniel Gray (Lanham, MD: Rowman and Littlefield, 2014), 60; Bell, "Bulgaria," 220. 
„дебатата на двете фракции не била за марксизмот наспроти немарксизмот, туку повеќе за соодветното разбирање и примена на марксистичките принципи во бугарското општество“18. Во секој случај, последиците од поделбата која произлегла од дебатите и судирите на БРСДП до 1903 г. било идеолошкото приврзување за Марксовиот Кайиच̄ал, кое понатаму, во 1919 г., ќе им помогне на бугарските тесни социјалисти да го развијат својот идентитет од „социјалдемократи“ и „социјалисти“ во „комунисти“.

Во нелегалниот период на БКП, 1923-44 г., се појавиле повторни изданија на преводите на Благоев и на Бакалов, и секој од нив добил ново издание, во две последователни години (1930/31 г.), и двете уредени од Тодор Павлов. Во овој период, може да се забележат последиците од политичкиот прогон кои произлегуваат од силна идентификација со и политичка работа за марксизмот (во овој случај, имајте предвид дека изданието на Тодор Павлов на преводот на Бакалов му се припишува на „Ж. Иванов“ - псевдонимот на Бакалов ${ }^{19}$, но Благоев исто така користел псевдоними, како „Желјазков“, уште од претходно). Што е најважно за мојот преглед, овој период го обележува доаѓњето на Тодор Павлов (1890-1977) на сцената на бугарската филозофија и марксизам. Во 1919 г., ѝ се придружил на комунистичката партија на Благоев која се разделила приклучувајќи ѝ се на Третата интернационала ${ }^{20}$. Во ова време, Павлов, кој потоа станал прв регент на Кралството Бугарија по државниот удар во 1944 г.

18 Dimou, "Entangled Paths," 174.

19 За псевдонимите на бугарските социјалисти, видете Pundeff, "Marxism in Bulgaria before 1891," 535-6 n.46.

20 "Bulgarian Communist Party (BCP)," in Historical Dictionary of Marxism, $2^{\text {nd }}$ edition, ed. by Elliott Johnson, David Walker, and Daniel Gray (Lanham, MD: Rowman and Littlefield, 2014), 60; Bell, "Bulgaria," 220. time, Pavlov, who then became the first regent of the Kingdom of Bulgaria after the 1944 coup and the most influential Bulgarian Marxist philosopher deep into the early 1960s, had just received amnesty (1929) for being complicit with the Sveta Nedelya bombing in Sofia in 1925. After having edited the two translations in 1930/1, he fled to Russia in 1932 where he became a professor in dialectical materialism (hereafter diamat) in Moscow at the Institute for Red Professorship and came back home only in 1936. Pavlov experienced the fury and brutality of the Bulgarian anticommunist reaction, being arrested in 1923 and 1925, and interned in various camps in the period 1941/43 after his 1936 return.

Pavlov's influence and power will be felt for the years to come - in fact, he was already shaping the reception of Marx and the direction of Marxism in the tumultuous illegal period of BCP. Yet I cannot emphasize enough how important is the fact that both Blagoev's and Bakalov's translations were made from the German, and this fact should be juxtaposed to the Russian literary influence that the ilk of Pavlov brought with their reintegration in Bulgarian society after 1944. The ensuing publishing history of Capital post-1944 is a direct reflection of a gnoseological isomorphism between satellite loyalty in both the party and in the language shaped by the institutional Marxist-Leninist establishments derivative of Moscow. Given that Blagoev was able to provide a direct translation of Capital, and given that Pavlov could edit the translations most likely in comparison to the Russian translation of Skvortsov-Stepanov (a fact I was not able to prove), it is unfortunate (though somewhat expected) that the publishing history of Capital after Pavlov's re-editions will rely almost exclusively on the Russian translations. What followed after Blagoev's and Bakalov's translations was, lexically speaking, an unfortunate turn to the Russian gravitational pull: unfortunate not because the Russian translations are 
и највлијателниот бугарски марксистички филозоф се́ до раните 1960-ти, штотуку добил амнестија (1929 г.) затоа што се согласил со бомбардирањето на катедралата „Света Недела” во Софија во 1925 г. По уредувањето на двата превода во 1930/1931 г., избегал во Русија во 1932 г. каде што станал професор по дијалектички материјализам во Москва на Институтот за црвени професори и се вратил дома дури во 1936 г. Павлов ги искусил лутината и бруталноста на бугарската антикомунистичка реакција; бил уапсен во 1923 г. и 1925 г. и бил во разни кампови во периодот 1941-43 по враќањето во 1936 г.

Влијанието и моќта на Павлов се чувствувале во следните години - всушност, тој веќе ги обликувал прифаќањето на Маркс и правецот на марксизмот во бурниот нелегален период на БКП. Сепак, не можам да истакнам доволно колку е важен фактот што преводите на Благоев и на Бакалов биле направени од германски, и овој факт треба да биде разгледан наспроти руското литерарно влијание што таквите како Павлов го донеле со нивната реинтеграција во бугарското општество по 1944 г. Историјата на

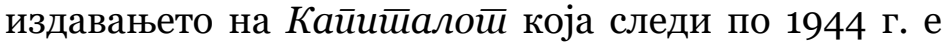
директен одраз на гносеолошкиот изоморфизам помеѓу сателитската лојалност и на партијата и на јазикот обликувани од марксистичко-ленинистичките институции произлезени од Москва. Со оглед на тоа што Благоев можел да даде директен превод

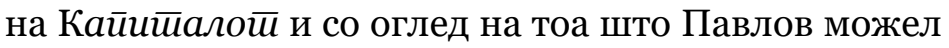
да ги уредува преводите најверојатно споредувајќи ги со рускиот превод на Скворцов-Степанов (факт кој не успеав да го докажам), штета е (иако донекаде и очекувано) што издавачката историја на

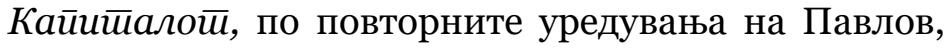
ќе зависат речиси исклучиво од руските преводи. Она што следело по преводите на Благоев и на Бакалов било, лексички кажано, несреќно свртување flawed (though they could certainly be, ideologically), ${ }^{21}$ but because the Bulgarian audience was able to read translations from the original from early on. The fact that Bulgarian and Russian are from the same Slavic Sprachbund and that at the late nineteenth century there was already a Russophile movement which certainly bore an imprint on the Bulgarian (Marxist) vocabulary does not explain away the party line followed later by the $\mathrm{BCP}$ to use Russian editions and re-translations. And whatever Pavlov had to learn from these two translations could not and was not integrated in the future editions overseen by the Party. For all of the above reasons, one should be very skeptical in qualifying the Bulgarian reception of Capital a "Bulgarian" one indeed. It is a synthesis of the already existing Rossophile-influenced literature, translations from the German, and the post1944 political satellite structure of Bulgarian science.

\section{III.}

A new period in Capital's dissemination and reception opened after 1944. It is this period that is centerpiece in my attempt to figure out the so-called relaxed irrelevance of the critique of political economy under Bulgarian Marxism and histmat. We can call this the systematic period. There is no edition of Capital between Pavlov's overseen translations in 1930/31 and 1948. This changed in 1948 (the so-called Dimitrov's constitution was voted in 1947) with a full re-translation of Capital, Vol. 1 from Russian. The first truly systematic edition of Vols. 1-3 is from the Bulgarian MEGA edition in Vols. 23-25, 1968.

21 See, as an example in surveying the Bulgarian history of Marx-Engels translations, Stanimir Panayotov, “Za 'samoizmenenieto,"' in Marks: heterogenni prochiti ot XX $v e k$, ed. by Haralambi Panitsidis, Emilia Mineva and Stanimir Panayotov (Sofia: Anarres, 2012), 652-7. 
кон руската гравитациска тежа: несреќно не затоа што руските преводи се со грешки (иако секако би можеле да бидат, идеолошки гледано) ${ }^{21}$, туку затоа што бугарската публика можела да ги чита преводите од оригиналот уште претходно. Фактот што бугарскиот и рускиот јазик се од истиот словенски Sprachbund и што во доцниот 19. век веќе имало русофилско движење што секако носело обележја на бугарски (марксистички) вокабулар, не ја оправдува партиската линија следена подоцна од БКП да се користат руските изданија и повторни преводи. И што и да имал да научи Павлов од овие два преводи, не можело и не било вклучено во идните изданија кои ги надгледувала Партијата. Од сите погоре наведени причини, би требало да се биде многу скептичен во квалификувањето на бугарскиот прием на

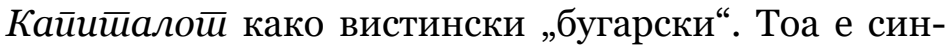
теза на веќе постојната литература под русофилско влијание, преводите од германски јазик и политичката сателитска структура на бугарската наука по $1944 \Gamma$.

\section{III.}

По 1944 г. се отворил нов период на ширење и при-

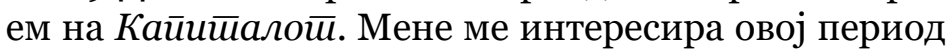
во обидот да ја откријам таканаречената релаксирана ирелевантност на критиката на политичката економија под бугарскиот марксизам и историскиот материјализам. Овој период ќе го наречеме си-

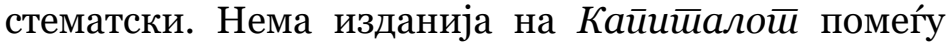

21 Видете, како пример во испитувањето на бугарската историја на преводите на Маркс и Енгелс, Станимир Панайотов, „За ,самоизменението““, во Маркс: хетерогенни прочити от $X X$ век, съст. Хараламби Паницидис, Емилия Минева и Станимир Панайотов (София: Анарес, 2012), 652-7.
The 1948-1956/66 full edition (including the three subvolumes of Vol. 4) is not easily labeled "systematic."

It is important to look at the publishing history of Capital via the Russian re-translation here because this history indexes the Bulgarian reception of Capital precisely as a Soviet scientific extension, while at the same time having political and institutional consequences much beyond the lexical concerns. There is a lot of ambiguity in the Bulgarian MEGA edition as to which volume is translated from Russian or German. Karl Sabitaev, a Germanist who worked in the Bulgarian MEGA team, certainly translated it from German, but his involvement in later editions of Capital as a translator cannot have been that profound, as those of the credited translators of Vol. 1, for example, in the 1955 Partizdat edition credits the names listed in the 1948 Russian translation. Whatever Sabitaev's (and others Germanists') contributions to diversifying the 1948 Russian retranslation of Capital/ MEGA in Bulgarian with expertise in German was, it is very likely that there is no translation from German, instead the translation was a result of what became the standard practice in socialist publishing - consultation and corroboration (sverka) of the Bulgarian retranslation from the Russian with the German original.

The conjuncture in this case involves two factors: the satellite structure of Bulgarian communist science since 1947 (see below, next paragraph) and the scientific community's parochialism stemming from close institutional collaboration with (not to say subjugation by) Soviet educational and scientific elite entities. Not that the post-1953 Soviet scientific world imposed that, on the contrary. In short, the efforts by Bulgarian Germanists such as Sabitaev should be seen as harnessed to prevent translation whims from Russian, and not towards building a conceptual translation in line with Bulgarian lexis and local Marxist concept-making. 
надгледуваните преводи на Павлов од 1930/1931 г. и 1948 г. Ова се сменило во 1948 г. (таканаречениот устав на Димитров бил изгласан во 1947 г.) со цело-

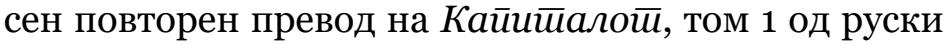
јазик. Првото вистински систематско издание на томовите 1-3 е од бугарското издание на MEGA, во томовите 23-25, 1968 г. Не е лесно потполното издание 1948-1956/66 г. (вклучувајќи ги трите подтомови од том 4) да се етикетира како „систематско“.

Важно е тука да се погледне историјата на издавањето

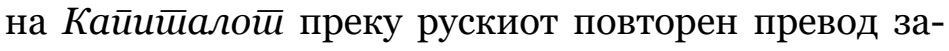
тоа што оваа историја го наведува бугарскиот прием прецизно како советско научно продолжение и има политички и институционални последици кои многу ја надминуваат лексичката област. Има многу нејасности во бугарското издание на MEGA во однос на тоа кој том е преведен од руски или германски. Карл Сабитаев, германист кој работел во бугарскиот тим на MEGA, секако преведувал од германски, но неговата вклученост во подоцнежните изданија

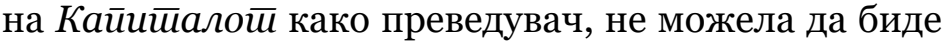
толку комплетна како таа на наведените преведувачи на том 1, на пример, во изданието на Партиздат од 1955 г., наведени се истите имиња како во рускиот превод од 1948 г. Какви и да биле придонесите на Сабитаев (и на други германисти) во развивањето на рускиот повторен превод од 1948 г. на Кайийалой/ MEGA на бугарски, веројатно е дека нема превод од германски, туку - како што станало стандард во социјалистичкото издаваштво - консултација и соработка (сверка) на бугарскиот повторен превод од руски со германскиот оригинал.

Во овој случај се работи за два фактора: сателитската структура на бугарската комунистичка наука од 1947 г. (видете подолу, следен став) и малограѓанството на научната заедница кое произлегува од тесната институционална соработка со (да не речам потчи-
Now, I will turn to explaining some connections between Bulgarian Marxism and the party infrastructure. If 1953 was something of an illusionary thaw, then the local reignition of scientific enthusiasm had to find its own institutional reins. Thus, the very same 1953 saw the founding of the Institute for the History of BCP, itself preceded by the earlier Central Party School, founded in 1945, which in 1957 became the Stanke Dimitrov Higher Party School. The Institute reported directly to the Party's Central Committee; the same became true for the Stanke Dimitrov School in 1969, when it transformed into the Academy of Social Sciences and Social Management (ASSSM), which, with its ten institutes, was hardly distinguishable from the BCP Institute. Unsurprisingly, it disappeared from the radar of history in 1990 just as the HEI Marx bust did. It was the headquarters of ASSSM that after 1990 were reappropriated for the establishment of the New Bulgarian University; other countryside buildings became the hosts of three newly established universities. The fate of Capital, political economy, statues and memorials, buildings and institutions seem to be interlocked in the historical juncture of 1953.

Much of the post-1990 Bulgarian democracy-makers turned neoliberals, with the adjacent revisionist historiography of the past, were trained in ASSSM in socalled scientific communism; the same is true for those unapologetic Marxists who remained in the background of the new historical situation. Representatives of HEI, some of whom still teach at UNWE, were also trained in ASSSM. Today UNWE hosts the only department of political economy, and unapologetically so, ${ }^{22}$ offering a

22 See Svetla Toshkova, "Politicheskata ikonomiya stava vse poneobhodima," Vestnik na UNSS, No. 598, June 28, 2012, 7. Note Toshkova's articles is featured in the same issue in which UNWE defended the reinstatement of Marx's bust against the protests of an anonymous mothers' organization, see above note 3 . 
нетост од) советските елитни образовни и научни тела. Не дека научниот свет по 1953 г. го наметнувал тоа, напротив. Накусо, на напорите на бугарските германисти, како Сабитаев, треба да се гледа како на метод за спречување на преведувачки спонтани интервенции од рускиот, а не како градење на концептуален превод во согласност со бугарската лексика и локалното марксистичко создавање концепти.

Сега ќе објаснам некои врски помеѓу бугарскиот марксизам и партиската инфраструктура. Ако 1953 г. била илузорно оладување, тогаш повторното локално разгорување на научниот ентузијазам морало да најде свои институционални узди. Во истата 1953 г. се формирал Институтот за историја на БКП, на кој му претходела раната Школа на централната партија, основана во 1945 година, која во 1957 година станала Висока партиска школа „Станке Димитров“. Институтот директно му поднесувал извештаи на Централниот комитет на партијата; истото се случило и со школата „Станке Димитров“ во 1969 г., кога се претворила во Академија за општествени науки и општествено управување (АОНОУ), која со своите десет институти, едвај се разликувала од Институтот на БКП. Неизненадувачки, исчезнала од историскиот радар во 1990 г., исто како што исчезнала бистата на Маркс на ВЕИ. Седиштето на AOHOУ по 1990 г. било повторно присвоено за основање на Новиот бугарски универзитет; а други рурални згради станале седишта на три новоосновани универзитети.

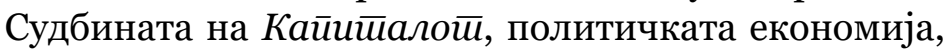
статуите и паметниците, зградите и институциите, се чинеле заглавени во историскиот јазол на 1953 г.

Многу од бугарските творци на демократијата по 1990 г. кои станале неолиберали, со блиската ревизионистичка историографија на минатото, биле обучувани во АОНОУ, во таканаречениот научен комунизам; истото важи и за тврдокорните маркси- degree programme as of 2011; this time, however, the UNWE and Toshkova in particular seek to legitimize the programme by referring to prestigious western universities offering similar degrees in much the same way as UNWE's Council seeks to defend the bust's reinstallment by citing BBC's 2008 poll.

To understand the reception of Marx's political economy and the way it intersected with a Soviet/satellite notion of histmat, I will give several examples in trying to unearth the "originality" of the Soviet-Bulgarian synthesis in various institutional and genre outlets, and through them I will also try to explain the retardation of that originality. Due to lack of space I will here discuss only the post-1944 literature and the institutional circumstances.

Post-Stalinist Bulgaria did not see an interest in questions of human subjectivity which received a relative popularity among other satellite states such as Hungary and Poland. On the contrary, BCP heaped scorn on internal oppositions throughout Warsaw Pact countries and, in line with its own 1956 April Plenum line, and playing 'holier than thou' with the USSR, indulged in demonstrative demonization of the Hungarian revolt. Thus, as Tsatsov claims, one of the characteristics of Bulgarian Marxism until the late 1960s, when a theoretical reorganization around the topic of "activity" happened, is the lack of interest in humanitarian and anthropological questions, instead, "emphasis was put on social-ideological questions and those that are ontological-epistemological." ${ }^{23}$ Tsatsov calls this "hard philosophizing," which transformed into party-licensed apologetic of Stalinist dogmatism.

Following the BS line, one could partly see how the Soviet-Bulgarian Marxist synthesis evolved - through a struggle for theoretical legitimacy mediated by the

23 Tsatsov, Dogmatitsi i revizionisti, 23. 
сти кои останале во заднината на новата историска ситуација. Претставниците на ВЕИ, од кои некои и денес предаваат на УНСЕ, исто така биле обучувани во АОНОУ. Денес на УНСЕ се наоѓа единствениот оддел за политичка економија ${ }^{22}$ и нуди академска програма од 2011 г., сепак УНСЕ и, особено, Тошкова, сакаат да ја оправдаат програмата наведувајќи престижни западни универзитети што нудат слични академски програми; повеќе или помалку, Советот на УНСЕ го брани враќањето на бистата, повикувајќи се на анкетата на Би-Би-Си од 2008 г.

За да го разбереме приемот на политичката економија на Маркс и начинот на кој се косела со советска/ сателитска идеја за историски материјализам, давам неколку примери за да ја откријам „оригиналноста“ на советско-бугарската синтеза во разни институционални и жанровски изрази, и преку нив, исто така ќе се обидам да го објаснам ретардирањето на таа оригиналност. Поради ограничување на просторот, ќе дискутирам само за литературата и за институционалните околности по 1944 г.

На постсталинистичка Бугарија не ѝ биле интересни прашањата за човечката субјективност кои станале релативно популарни помеѓ сателитите како Унгарија и Полска. Напротив, БКП ги напаѓала интерните спротивставувања во земјите на Варшавскиот пакт и, во согласност со сопствената линија од Априлскиот пленум во 1956 г., и правејќк се посвета од СССР, почнала демонстративно да го демонизира унгарскиот револт. Како што тврди Цацов,

22 Видете Светла Тошкова, „Политическата икономия става все по-необходима“, Вестник на УНСС, No. 598, 28 јуни 2012, 7. Имајте предвид дека написот на Тошкова е даден во истото издание во кое УНСЕ го брани враќањето на Марксовата биста и покрај протестите на анонимна организација на мајки, видете погоре, заб. 3. construction of a proletariat and its class history. In this period the literature did see a continuation of the NS-BS debates to a lesser extent, and in philosophical circles mostly, but the histmat methodology practically ended them. This does not mean that the concern with "the applicability of Marxism" did not rule the day, but on the contrary, it can even be seen as a compensatory reaction. The literature was dominated by a newly found enthusiasm in publishing and translating, now free from persecution; in fact, the importance of translation will remain central also throughout the 1970s and 1980s at ASSSM and Sofia University.

The norm of (Soviet) histmat in Bulgarian historiography quickly arrived ${ }^{24}$ and then expanded to other fields of interest, especially philosophy, until it gradually blurred the lines between Soviet and Bulgarian "Marxism." The best example pertains to the attacks on Dimitar Mikhalchev, who is now glorified as an "anti-communist philosopher," but who partially accepted histmat's dogmas: that history is progress and that historical cycles follow patterns of human activities. Mikhalchev did remain active until the late 1940s, when he coexisted with Pavlov in Sofia University, but the price he had to pay for his particular compromised Marxism - a syntheses with Johannes Rehmke's work - was to be publicly attacked and stained as "revisionist" in the philosophical press throughout the 1950 s and 1960 s. $^{25}$

24 See note 14 .

25 The best study pertaining to Mikhalchev's Marxism and Rehmkeanism is by Dimitar Tsatsov, Osnovonauchnata filosofska shkola $v$ Balgariya. Vtorata polovina na XX vek (Sofia: Marin Drinov, 2011). A very representative attack is the 1954 (here republished) text by Elka Panova and Dobrin Spasov, "Krayat na balgarskata burzhoazna filosofiya (po povod Logikata na akad. D. Mikhalchev)," Filosofski alternativi, No. 2 (2013), 16-49. The philosopher responsible for receiving Mikhalchev as anti-communist is Mikhail Buchvarov, one of the chief historians of Bulgarian philosophy since the 1960s. 
една од карактеристиките на бугарскиот марксизам до доцните 1960-ти била, кога се случила теоретска реорганизација околу темата „активност“, немање интерес во хуманитарните и антрополошките прашања: „акцентот бил ставен на социо-идеолошки и онтолошко-епистемолошки прашања“23. Цацов ова го нарекува „жестоко филозофирање“ кое се претворило во партиски лиценцирано оправдување на сталинистичкиот догматизам.

Следејќи ја линијата на ШС, може делумно да се види како се развивала советско-бугарската марксистичка синтеза: преку борба за теоретска легитимност посредувана со градење на пролетаријат и негова класна историја. Во овој период, во литературата имало помалку продолжувања на дебатата меѓу ТС-ШС и главно во филозофските кругови, но методологијата на историскиот материјализам практично ги прекинала. Ова не значи дека загриженоста околу „применливоста на марксизмот“ не владее и денеска - напротив, дури може на неа да се гледа како на компензаторна реакција. Во литературата владеел новооткриен ентузијазам во издавањето и преведувањето, кое сега било ослободено од прогон; всушност, важноста на преводот ќ остане централна и во текот на 1970-тите и 1980-тите на АОНОУ и на Софискиот универзитет.

Нормата на советскиот историски материјализам во бугарската историографија пристигнала брзо ${ }^{24}$ и потоа се проширила на други полиња на интерес, особено во филозофијата, додека не ги замачкала границите меѓу советскиот и бугарскиот марксизам. Најдобриот пример се однесува на нападите врз Димитар Михалчев, кој сега го величаат како „антикомунистички филозоф“, но кој делумно ги при-

23 Цацов, Догматици и ревизионисти, 23.

24 Видете забелешка 14.
A late example of this is a discussion documenting one debate between both on a 1963 publication on Hegel by Mikhalchev, which reveals the party fervor and antagonism exercised. ${ }^{26}$ Mikhalchev was neither an avid reader of Marx, nor purely an anti-Marxist, but the orthodoxy of Pavlov, now in power in BAS' Institute of Philosophy (1949-1952 and 1960-1977), was relentless in its demonstrativity. There is no debate between Pavlov and his circles and Mikhalchev and his circles about the Capital or issues pertaining to the analyses of capital's contradictions, etc. The debates are purely gnoseological. Mikhalchev advocated "presentationism" of the scientific object (easily identified with "bourgeois idealism" and anti-Leninist materialism), while Pavlov advocated a "representative realism" closer to a monistic mind-matter correspondence theory. Its analytical subtleties like these that reveal what was at stake for party ideologues like Pavlov, who was also the chief philosopher in the country: questions of concern where closer, at best, to Lenin's Marx. But the attack on Mikhalchev was, strictly speaking, instrumental rather than conceptual one. For Pavlov, the real problem was not Mikhalchev's Remhkeanism, which is contemporaneous to the rise of diamat, but that there is no place for such philosophy after the arrival of Michurin's and Lysenko's ideas in 1949. ${ }^{27}$ It is biological, not economic, debates that put Mikhalchev away from the radar of the admissible.

In the period, when it comes to the educational dissemination of Marxist political economy, the influence of Alexander Leontiev's works was felt as they were used as some of the early textbooks. ${ }^{28}$ It is the

26 “Todor Pavlov sreshtu Isak Pasi," Kultura (2009), www. kultura.bg/media/my_html/mainpage/anty/33.htm.

27 Tsatsov, Domatitsi i revizionisti, 30-1.

28 Rakovodstvo po politicheska ikonomiya: marksicheska shkola. Sustav. po Marks, Borhard, Leontiev (Sofia: BCP, 1945); Alexander Leontiev, Kapitalat na Marks, translated 
фатил догмите на историскиот материјализам: дека историјата е напредок и дека историските циклуси следат шеми на човечки активности. Михалчев бил активен до доцните 1940-ти и бил современик на Павлов на Софискиот универзитет, но цената што морал да ја плати за својот личен компромитиран марксизам - синтеза со делото на Јоханес Ремке била јавен напад и обележување како „ревизионер“ меѓу филозофските издавачи во текот на 1950-тите и 1960-тите ${ }^{25}$. Подоцнежен пример е дискусијата со која се документира една дебата меѓу двајцата за публикација на Михалчев од 1963 г. за Хегел, која ги открива постојната партиска жестина и антагонизам $^{26}$. Михалчев не бил ниту страстен читател на Маркс, ниту вистински антимарксист: но ортодоксноста на Павлов, сега доминантна на Институтот за историја на БАН (1949-1952 и 1960-1977), била немилосрдна во својата демонстративност. Нема дебата помеѓу Павлов и неговите кругови и

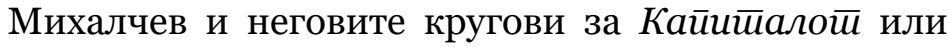
прашања кои произлегуваат од анализата на контрадикциите на капиталот, итн. Дебатите се чисто гносеолошки: Михалчев се залагал за „презентативност“ на научниот објект (кој лесно се идентифику-

25 Најдобрата студија која се однесува на Михалчевиот марксизам и ремкеанизам е од Димитър Цацов, Основонаучната философска школа в България.

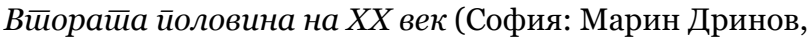
2011). Многу репрезентативен напад е текстот од 1954 г. (повторно издание) на Елка Панова и Добрин Спасов, „Краят на българската буржоазна философия (по повод Логикайа на акад. Д. Михалчев)“, Философски алтернативи, No. 2 (2013), 16-49. Филозофот одговорен за прифаќање на Михалчев како антикомунист е Михаил Бачваров, еден од главните историчари на бугарската филозофија од 1960-тите.

26 „Тодор Павлов срещу Исак Паси“, Култура (2009), www. kultura.bg/media/my_html/mainpage/anty/33.htm. same Leontiev that the Johnson-Forest Tendency in the US was targeted as the one to have unconsciously admitted that the labor theory of value has ceased to operate in the USSR's Stakhanovist model. ${ }^{29}$ (See below how JFT's thesis is inadvertently taken up by Bulgarian sociologists.)

To understand the lack of originality in the SovietBulgarian synthesis until the 1970s in this stage of the reception of Marx, I will return to the intellectual production of the Stanke Dimitrov School/ASSSM. A look at the bibliographical catalogue of philosophical periodicals in particular (such as those of Filosofska misal and Izvestiya/Nauchni trudove na AONSU pri TsK na BKP - filosofski serii) reveals little about a particular and significant Bulgarian commentary on Capital. Unsurprisingly, on the other hand, looking up at the index of an interwar journal such as Filosofski pregled (published 1929-1943), one finds only one publication on Marxism - and it is by Mikhalchev. The alleged anti-systemic quality Pavlov, Sava Ganovski and others wanted to find in Mikhalchev was certainly out of touch; but this did not make him an "anti-Marxist."

Without wanting to derogate the contributions of the likes of Pavlov and his famous theory of reflection, ${ }^{30}$

from the Russian by Renata Zh. Nathan (Sofia: Narodna kultura, 1949).

29 Raya Dunayevskaya, "Stalinists Falsify Marxism Anew. State of Teaching Marxism in the Soviet Union," Fourth International, Vol. 9, No. 7 (September 1948), 204-209, retrieved from Marxist Internet Archive, www.marxists.org/archive/ dunayevskaya/works/1948/stalinists-falsify.htm.

30 Originally published in Russian in 1936, it was preceded by his Remkeanstvo i materializam [Rehmkeanism and Materialism] (1930), which laid the grounds for his own original thought, see Todor Pavlov, The Philosophy of Todor Pavlov (Sofia: Sofia Press), 1970; see also Mineva, "On the 
ва со „буржоаски идеализам“ и антиленинистички материјализам), додека Павлов се залагал за „репрезентативен реализам“, поблизок до монистичката теорија за кореспонденција на умот-материјата. Ваквите аналитички суптилности откриваат што ги чекало партиските идеолози како Павлов, кои биле истовремено и главни и доминантни филозофи во земјата: прашањата кои се разгледувале биле поблизу до, најпрецизно кажано, Лениновиот Маркс. Но нападот врз Михалчев бил, конкретно говорејќи, повеќе инструментален отколку концептуален. За Павлов, вистинскиот проблем не бил Михалчевиот ремкеанизам, кој се појавил во исто време со дијалектичкиот материјализам, туку тоа што немало место за таква филозофија по пристигнувањето на идеите на Мичурин и Лисенко во $1949 \Gamma^{27}$. Биолошките, а не економските дебати го тргнале Михалчев од радарот на прифатливото.

Во тој период, што се однесува до образовното распространување на марксистичката политичка економија, влијанието на делата на Александар Леонтиев се почувствувало кога се користеле во некои од првите учебници ${ }^{28}$. Се работи за истиот Леонтиев што групата Џонсон-Форест во САД го одредила како оној кој несвесно признал дека трудовата теорија на вредноста престанала да функционира во Стахановиот модел на $\mathrm{CCCP}^{29}$. (Видете подолу како тезата на

27 Цацов, Догматици и ревизионисти, 30-1.

28 Ръководство по политическа икономия: марксическа школа. Състав. по Маркс, Борхард, Леонтиев (София: БКП, 1945); Александър Леонтиев, Капиталът на Маркс, превод от руски Рената Ж. Натан (София: Народна култура, 1949).

29 Raya Dunayevskaya, "Stalinists Falsify Marxism Anew. State of Teaching Marxism in the Soviet Union," Fourth International, Vol. 9, No. 7 (September 1948), 204-209, retrieved from Marxist Internet Archive, www.marxists.org/archive/ dunayevskaya/works/1948/stalinists-falsify.htm. which after all defined the scientific snowballing of diamat in the entire Soviet bloc and beyond, the relevant periodicals reveal that original research and commentary began surfacing in the 1970 s and intensified between the mid-1970s and the late 1980s.

Two other historical examples will illustrate the conceptual passivity of "Bulgarian Marxism." 1) After the April Plenum, the Institute of Philosophy at BAS organized a series of meetings in March-April 1956 spearheaded by a report from Raycho Karakolov called "The Principles of Building a Programme of Dialectical and Historical Materialism in Higher Education Institutions." The distinction between dogmatists and revisionists (with the latter suffocated and being exactly the ones who would have been allegedly able to produce original scholarship not on the Capital, but in general on Marx) that Tsatsov has studied and which was centered around the work of Lysenko and Michurin was in this process continued along the more specific lines of histmat's scientific and party role as organizing principle for the "cultural-creative intelligentsia." Svetla Koleva has studied this in detail: at this meeting, one can detect the genesis of a Soviet subservient Marxism as it produced two groups. The first one argued for the role of histmat as part and parcel of Marxist-Leninist philosophy which should be separated from diamat - so this histmat coincides with what would otherwise be Marxist sociology proper. The other group, which eventually lost the debate, treated histmat within the systematization provided by diamat by arguing for a principle of convergence between logics and history. This division's result was that in as much as histmat is thought of as the Marxist science of society par excellence, there

Reception," 66; Nina Dimitrova, "Balgarski filosofski kanon?," Nota Bene, No. 14 (2010), www.notabene-bg.org/read. php?id=149. 
групата Џонсон-Форест необмислено била преземена од бугарските социолози).

За да го разбереме недостигот од оригиналност во советско-бугарската синтеза до 1970-тите во оваа фаза на прифаќање на Маркс, ќе се навратам на интелектуалната продукција на Училиштето „Станке Димитров“/АОНОУ. Погледот на биографскиот каталог на, конкретно, филозофските месечни списанија (слични на оние на Философска мисъл и Известия) Научни трудове на АОНСУ йри ЦК на БКП - философски серии) открива малку за конкретен и важен

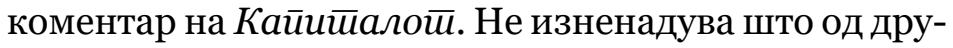
га страна, гледајќи го индексот на едно меѓувоено списание како Философски преглед (издадено во 1929-1943 г.), може да се најде само еgно издание за марксизмот - и тоа е од Михалчев. Наводниот антисистематски квалитет кои Павлов, Сава Гановски и други сакале да го најдат кај Михалчев бил недофатлив; но не бил поради тоа „антимарксист“.

Не сакајќи да ги потценува придонесите на сличните како Павлов и неговата позната теорија за рефлексија ${ }^{30}$, што најпосле го дефинирало научното масовно прифаќње на дијалектичкиот материјализам во целиот советски блок и пошироко, релевантните списанија откриваат дека оригиналните истражувања и коментари почнале да се појавуваат во 1970-тите и се интензивирале меѓу средината на 1970-тите и доцните 1980-ти.

30 Оригинално објавена на руски во 1936 г., ѝ претходел неговиот труд Ремкеанство и материализъм (1930), кој ги поставил основите на неговата сопствена оригинална мисла, видете Todor Pavlov, The Philosophy of Todor Pavlov (Sofia: Sofia Press), 1970; видете исто Mineva, "On the Reception,” 66; Нина Димитрова, „Български философски канон?", Nota Bene, No. 14 (2010), www.notabene-bg.org/ read.php?id=149. is no sociology proper..$^{31}$ And yet it is exactly in Bulgarian sociology where we will find original Marxist research (see below). 2) A meeting of philosophical workers took place on November 11-13, 1959, organized by the Science, Education and Arts section of BCP's Central Committee. It was based on a decision of the XXI Congress of CPSU, as well as a Zhivkov report to the National Assembly and a report of the same year on the development of science. This meeting saw the cracks opened between dogmatists and revisionists centered around the schools of idealism (Weissman) and materialism (Lysenko) in genetics. A fierce debate opened whether Weissmanism is idealist. As with Mikhalchev, the problem was whether it was possible to make an already existing current (here Weissmanism) cohabitate with diamat? And the answer was no.

\section{IV.}

Against this background, it is Bulgarian sociology, spearheaded in the early 1960 s by Zhivko Oshavkov, which will resist the Soviet histmat consensus. As PetarEmil Mitev notes, the paradox to which the ilk of Zhivkov would respond later was that "the ideological setting of the 1930s, a conflictual period in the history of the Kingdom of Bulgaria, turned out to be more favorable for the creative freedom of the Marxist Ivan Hadzhiiski than the dogmatic setting under the dominance of MarxismLeninism that Zhivko Oshavkov faced." ${ }^{2}$ This is the time of the mid-aged Zhivkov, who, as Bell describes

31 Svetla Koleva, Sotsiologiyata kato proekt. Nauchna identichnost $i$ sotsialni izpitaniya $v$ Balgariya 1945-1989 godina (Sofia: Pensoft, 2005), 141, 135.

32 Petar-Emil Mitev, "100 g. ot rozhdenieto na Zhivko Oshavkov: Ivan Hadzhiiski, Zhivko Oshavkov i nie," in Gradat i seloto - predizvikatelstvata na XXI vek, ed. by Galina Koleva and Dona Pikard (Sofia: Omda, 2014). 
Два дополнителни историски примери ќе ја илустрираат концептуалната пасивност на „бугарскиот марксизам“. 1) По Априлскиот пленум, Институтот за филозофија на БАН организирал серија состаноци во март-април 1956 г., поттикнат од извештај на Рајчо Караколов наречен „Принципите на градење на програмата на дијалектички и историски материјализам во повисоките образовни институции“. Разликата меѓу догматичарите и ревизионистите (последните се задушени и се оние кои наводно би биле во можност да произведат оригинално

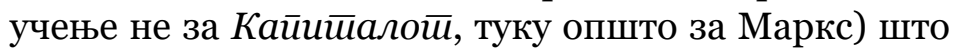
ја студирал Цацов и која се засновала на делата на Лисенко и Мичурин, во овој процес била продолжена по поспецифичните насоки на научната и партиската улога на историјата на материјализмот како организирачки принцип за „културно-креативната интелигенција“. Светла Колева го студирала ова детално: на оваа средба може да се забележи генезата на советски подреден марксизам кој создал две групи. Првата ја аргументирала улогата на историскиот материјализам како дел од марксистичко-ленинистичката филозофија која ишреба gа е оgвоена оg gијалекииччкиой майеријализам - така, овој историски материјализам се поклопува со она што инаку би била вистинска марксистичка социологија. Другата група, која накрај ја изгубила дебатата, го третирала историскиот материјализам во рамкиие на систематизацијата која ја дал дијалектичкиот материјализам аргументирајќи принцип на конвергирање помеѓу логиката и историјата. Резултатот на разделот бил тој што колку и да се мисли за историскиот материјализам како par excellence марксистичка наука за општеството, не постои вистинска социологија ${ }^{31}$. А сепак, токму во бугарската

31 Светла Колева, Социологията като проект. Научна идентичност и социални изпитания в България 19451989 година (София: Пенсофт, 2005), 141, 135. him, "has been a consistent, loyalist voice denying the possibility of genuine communism apart from the Soviet model and apart from Soviet leadership."33 This was registered in the scientific activities much earlier (the 1949 example with the arrival of Lysenkovism), and it eventually led to an opposition between sociology as a "bourgeois science" and histmat/scientific communism, which was already seen as the science of the society. But from the late 1950s onwards, which saw the division between dogmatists and revisionist, communists' own proprioception in science registered as its great successes "[the] geological science which helped to find and utilize in industry new resources, as well as biological sciences ... the biggest number of philosophical workers was in the area of biology." 34

Oshavkov and Jacques Nathan made sure that HEI will develop a distinct sociology of labor by 1969. The vanguard of research can be attributed to Oshavkov's Istoricheski materializam i sotsiologiya [Historical Materialism and Sociology ${ }^{35}$ ] (1958), credited to have reinstated the sociological correspondence between theory and empirical data, so much in need under the eye of dogmatists. One specific way in which others have followed in his footsteps is the work on the behavior of young people. For example, Petar-Emil Mitev took up the Institute for the young at BAS (1967-8) and carried as a new method the "indirect poll," utilizing Jenny Marx's questionnaire to his father, which gathered enormous interest and results and let the team to the notion of individualization/juvenalization - a notion that will

33 Bell, "Bulgaria," 234.

34 Tsatsov, Dogmatitsi i revizionisti, 30, 32.

35 Sofia: Nauka i izkustvo, 1970; see also Zhivko Oshavkov, "Glavni etapi na prehoda ot kapitalizma kam komunizma," Filosofksa misal, No. 1 (1961), 26-46. 
социологија ќе најдеме оригинално марксистичко истражување (видете подолу). 2) Средба на филозофски работници се одржала од 11-13 ноември 1959 г., организирана од Одделот за наука, образование и уметност на централниот комитет на БКП. Била заснована на одлуката на XXI конгрес на КПСС, како и на извештајот на Живков до Националното собрание и извештајот од истата година за развојот на науката. На оваа средба се појавиле пукнатини помеѓу догматичарите и ревизионистите собрани околу школите на идеализам (Вајсман) и материјализам (Лисенко) во генетиката. Се отворила жестока дебата околу тоа дали вајсманизмот е идеализам. Како и со Михалчев, проблемот бил: Дали може да се направи веќе постојна струја (во случајот вајсманизмот) да постои заедно со дијалектичкиот материјализам? Одговорот бил, не.

\section{IV.}

Со ваков историјат, токму бугарската социологија, поттикната во раните 1960-ти од Живко Ошавков, ќе му се спротивстави на консензусот на советскиот историски материјализам. Како што забележува Петар-Емил Митев, парадоксот на кој таквите како Живков ќе одговорат подоцна бил дека „идеолошката средина на 1930-тите, конфликтен период во историјата на Кралството Бугарија, излегол поповолен за креативната слобода на марксистот Иван Хаџииски од догматската поставка под доминација на марксизмот-ленинизмот со кој се соочувал Живко Ошавков“32. Ова е времето на средовечниот Живков, кој, како што го опишува Бел, „бил постојан лојалистички глас кој ја негирал можноста за ви-

32 Петър-Емил Митев, „100 г. от рождението на Живко Ошавков: Иван Хаджийски, Живко Ошавков и ние“, во Градът и селото - предизвикателствата на ХХІ век, съст. Галина Колева и Дона Пикард (София: Омда, 2014). eventually describe a shortage of personal space among the young people of the 1960 s generation. ${ }^{36}$

This was a relative relaxation in practicing social sciences after the dramatic 1950s, which offered a politically instrumentalized version of Marxism. As with genetics, a debate on sociology vs histmat from the 1950 s followed. The evidence gathered by Koleva, Nenkova and Treneva through interviews sheds some light on the opposition to sociology's political instrumentalization as histmat pure and simple, and the need to engage meaningfully with Marx, a phenomenon that will blossom in philosophy in the 1980 s due to the work done by Mitev and his student Emilia Mineva's work on the young Marx.

In his interview Kiril Vasilev says that "we developed sociology as science without prejudice. Capital is alright, the 'Economic Manuscripts' - too. What ideology is there! While The Communist Manifesto is ideology, its entire pathos is ideological." ${ }^{37}$ Vasilev refers to the period after Khruschev's 1956 "secret speech.” As Stefan Donchev says, "Marxism was the state ideology until 1955 for the Todor Pavlov and his movement, the Marxism-Leninism." ${ }^{8}$ And Stoyan Mihaylov states that "[we wanted] to integrate a real Marxist approach and a real Marxist atmosphere in the party." ${ }^{39}$ Apparently, Bulgarian sociologists saw potential to do so by wishing to engage with Capital in some ways. Mihaylov further states that the most unfortunate dogma in Bulgarian scientific communism/Marxism was the idea that

36 "Interview with Petar-Emil Mitev," in Sotsiologiyata prez pogleda na pokoleniyata (intervyuta s balgarski sotsiolozi), ed. by Svetla Koleva, Diana Nenkova and Simona Treneva (Sofia: Pensoft, 2012), 111.

37 Ibid., 21.

38 Ibid., 133.

39 Ibid., 45. 
стински комунизам покрај советскиот модел и одвоено од советското водство“33. Ова секако било регистрирано во научните активности многу порано (примерот од 1949 г. со пристигнувањето на лисенковизмот) и потоа довело до опозиција помеѓу социологијата како „буржоаска наука“ наспроти историскиот материјализам/научниот комунизам, на кој веќе се гледало како на наука за општеството. Но од доцните 1950-ти понатаму, период во кој настанал раздел меѓу догматичарите и ревизионистите, во сопствената проприоцепција на комунистите во науката била регистрирана како нивен голем успех „геолошка[та] наука која помогнала да се најдат и искористат нови ресурси во индустријата, како и биолошки науки ... најголемиот број филозофски работници биле во областа на биологијата“"34.

Ошавков и Жак Натан се погрижиле ВЕИ да развие дистинктивна социологија на трудот до 1969 г. Почетоците на истражувањето може да се поврзат со Исторически материализъм и социология (1958) ${ }^{35}$ на Ошавков, кому му се припишуваат заслуги за повторно воспоставување на социолошката преписка меѓу теоријата и потребните емпириски податоци под окото на догматичарите. Конкретен начин на кој други ги следеле неговите стапки е работењето на однесувањето на младите. На пример, Петар-Емил Митев го презел Институтот за млади лица на БАН (1967-1968) и како нов метод ја користел „посредната анкета“, користејќи го прашалникот на кој Џени Маркс го користела за нејзиниот татко, кој предизвикал огромен интерес и резултати и му ја претставил идејата за индивидуализирање/подмладување
33 Bell, "Bulgaria," 234.

34 Цацов, Догматици и ревизионисти, 30, 32.

35 София: Наука и изкуство, 1970; видете исто Живко Ошавков, „Главни етапи на прехода от капитализма към комунизма“, Философска мисъл, No. 1 (1961), 26-46. capitalism is incapable of development. ${ }^{40}$ Others, like Chavdar Kyuranov claim there was no feeling of "oppression by the ideology, but oppression from the party bureaucracy." ${ }^{11}$ Mincho Semov's observation is central to this analysis: he claims that the "specific research work was destroying dogmatism."42 According to him, the dogmatism was the byproduct of Bukharin's thesis that historical materialism is science, and that therefore there is no need for sociology as there is already scientific communism (and the identity with histmat therewith).

It seems that over time those sociologists who disagreed with the identity of sociology with histmat dominated by the March-April 1956 events found ways to subvert Soviet-style formalism. The cracks of the SovietBulgarian synthesis were opened by sociologists by looking critically at value theory. As Zakhari Staykov claims, "Marxism was devoid of the most important teaching of Marx - surplus value." ${ }^{43}$ Here, it is worth recalling that Dunayevskaya, a JFT representative, when attacking Leontiev's pedagogical streamlining of Capital, has said that "[w]ith the demand for a theory of value that was not at the same time a theory of surplus value, the Stalinists tried to divest the labor theory of value of its class content." 44 Put in relative scientific isolation, Bulgarian sociologists observed the same phenomenon, hence Staykov's comment that “[s]ociety becomes wealthier only if it works more! Because wealth equals surplus value. Which is what Marxists under [Bulgarian] socialism wanted to get rid of." 45 If we are to

40 Ibid., 53.

41 Ibid., 81.

42 Ibid., 88.

43 Ibid, 120.

44 Dunayevskaya, "Stalinists Falsify Marxism."

45 Koleva, Nenkova and Treneva, Sotsiologiyata prez pogleda, 127. 
- идеја што во крајна линија ќе го опише недостатокот на личен простор помеѓу младите лица на генерацијата од 1960-тите ${ }^{36}$.

Ова претставувало релативно релаксирање во практикувањето општествени науки по драматичните 1950-ти, кои понудиле политички инструментализирана верзија на марксизмот. Како и со генетиката, од 1950-тата следела дебата за социологијата наспроти историскиот материјализам. Доказите собрани од Колева, Ненкова и Тренева преку интервјуа, ги разјасниле спротивставувањето на општествената политичка инструментализација како чист и едноставен историски материјализам и потребата од подлабок анганжман со Маркс, феномен што ќе се развие во филозофијата во 1980-тите поради делата на Митев и неговата студентка Емилија Минева за младиот Маркс.

Во своето интервју, Кирил Василев вели дека „ја развивме социологијата како наука без предра-

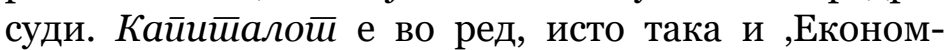
ските ракописи“. Каква идеологија е во прашање! Комунисииччкиой манифесии е идеологија, а целиот патос е идеолошки“37. Василев зборува за периодот по „тајниот говор“ на Хрушчов. Како што вели Стефан Дончев „Марксизмот бил државна идеологија до 1955 г. за Тодор Павлов и неговото движење, марксизмот-ленинизмот“38. И Стојан Михајлов вели дека „[сакавме] да интегрираме вистински марксистички пристап и вистинска марксистичка атмосфера во партијата“39. Наводно, бугарски-

36 „Интервю с Петър-Емил Митев“, во Социологията през погледа на поколенията (интервюта с български социолози), съст. Светла Колева, Диана Ненкова и Симона Тренева (София: Пенсофт, 2012), 111.

37 Ibid., 21.

38 Ibid., 133 .

39 Ibid., 45 . trust all of these accounts, then Capital under the SovietBulgarian synthesis was devoid of its greatest value (or so they thought) - surplus value theory.

Another way in which Bulgarian sociology managed to salvage Marx and be original was through Hegelian accounts. This is also to some extent due to Oshavkov's work: as Stefan Donchev says, Oshavkov "managed to connect the systemic approach and in fact the structuralfunctional one with Hegel, with his Greater Logic, which is actually the systemic approach. Marx uses the systemic approach. And he [Oshavkov] struggled to prove that he derives from Marx, so that he is not blamed for practicing Weberianism." ${ }^{6}$ Similarly, Viktor Samuilov says that back in the 1960s he decided to pursue philosophy after he graduated from political economy because "in order to understand Capital you have to understand Hegel's Logic."47 Later, representatives of Bulgarian sociology will nurture a particular and dear relationship to Hegel's Logic, yet not always in order to either praise Marx or merely divert productively from party lines to save their personal and professional spaces. As Mark Baskin has observed in the late 1980s and early 1990s, while "Zhivkov's ancien régime began to decay, a genuine Bulgarian critical Marxism emerged as an effort to revive a spirit of opposition and mass movement within the BSP." 48 This did not prevent Niko Iakhiel to claim as late as 1988 that "our sociology is the party's science...,"49 perhaps being unable to delink histmat from "sociology" for all the wrong reasons.

46 Ibid.,129.

47 Ibid., 186.

48 Mark Baskin, "Bulgaria: From Critique to Civil Society?," in The Road to Disillusion: From Critical Marxism to Postcommunism in Eastern Europe, ed. by Raymond C. Taras (Armonk, New York: M.E. Sharpe, 1992), 153.

49 Cited in ibid. 
те социјалисти виделе потенцијал да го направат

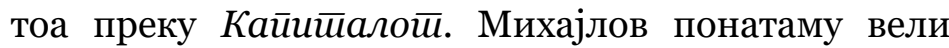
дека најнесреќната догма во бугарскиот научен комунизам/марксизам била идејата дека капитализмот нема можност за развој ${ }^{40}$. Други, како Чавдар Кјуранов тврдат дека немало чувство на „угнетеност од идеологијата, туку од партиската бирократија“41. Согледувањето на Минчо Семов е главно за оваа анализа: тој тврди дека „конкретната истражувачка работа го уништувала догматизмот“42. Според него, догматизмот бил нуспроизвод на тезата на Бухарин дека историскиот материјализам $е$ наука и дека затоа нема потреба од социологија, бидејќи веќе има научен комунизам (и со тоа, идентичност со историскиот материјализам).

Се чини дека со тек на време, социолозите што не се согласувале со идентичноста на социологијата со историскиот материјализам, нешто што преовладувало во настаните од март до април 1956 г., нашле начини да го поткопаат формализмот во советски стил. Пукнатините во советско-бугарската синтеза ги направиле социолозите кои критички гледале на теоријата на вредност. Како што тврди Захари Стајков, „марксизмот бил лишен од најважното учење на Маркс - вишокот вредност“43. Тука треба да се потсетиме на Дунајевскаја, претставник на групата Џонсон-Форест, која, кога го напаѓа Леонтиевото

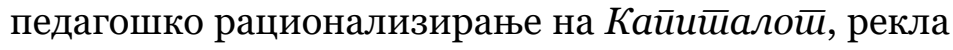
дека „[с]о барањето теорија на вредност што не била во исто време теорија на вишокот вредност, сталинистите се обиделе да ѝ ја одземат класната содржина на трудовата теорија на вредноста“"44. Ставени во
43 Ibid, 120.

44 Dunayevskaya, "Stalinists Falsify Marxism."
Along with the Hegelian influence, the decisive line of original research will be pursued due to the visit of the Georgian philosopher Merab Mamrdashvili to Bulgaria in the 1970s. There he spoke to the then younger generation, and left an imprint upon Bulgarian sociological culture, leaving an odd sociological reception that will slowly help emancipate Marxist scholarship, in particularly due to his writing on "non-classical rationality" and his article on Marx's "verwandelten formen." There was already an interest at the Faculty of Philosophy in the work of Evald Ilyenkov and his Dialectical Logic. Deyan Deyanov will take up the project of rewriting the logic of Capital in a series of scattered articles that appeared mostly in the 1990s; yet the defining moment was the intellectual production of what was called the "Marx Seminar," which was predominantly a synthesis between Marx and other writers (Freud, Weber, Simmel, etc.) and represented an attempt at exercising phenomenological sociology. Delchev's dissertation seems to be a good example of how one can engage with Hegel by indulging in the logic of Capital. ${ }^{50}$ Perhaps the word "autonomous" rather than "original" describes better these scientific activities centered as they were on Marx and/via Hegel, nurtured under the influence of Oshavkov and Stoyan Mihaylov.

50 See "Interview with Deyan Deyanov," in Koleva, Nenkova and Treneva, Sotsiologiyata prez pogleda, 280-81; some examples: Deyan Deyanov, Kolyo Koev and Deyan Kyuranov, "Mladiyat Marks kato kritik: ot zhurnalistika kam teoriya," Filosofska misal, No. 11 (1983), 85-94; the dissertation of Krassimir Delchev, Sravnitelen analiz na nyakoi dialekticheski momenti $v$ glava parva na Kapitalat na Marks $i$ Naukata logika na Hegel (Sofia: Sofia University, 1987); as well as Deyan Kyuranov's dissertation published as: Ot opozitsiya kam pozitsiya. Hegel, Foyerbah, Marks - iz metodologiyata na XX vek (Sofia: Nauka i izkustvo, 1989); Deyan Deyanov and Georgi Kapriev, “'Hegelovata logika' na Marks," Filosofska misal, No. 9 (1988), 66-9. 
релативна научна изолација, бугарските социолози го забележале истиот феномен, оттаму коментарот на Стајков дека „[о]пштеството станува побогато само ако работи повеќе! Богатството е еднакво на вишок вредност. Тоа е она од што марксистите во [бугарскиот] социјализам сакаат да се ослободат“45. Ако им веруваме на сите овие гледишта, тогаш

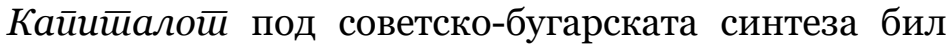
лишен од својата најголема вредност (или така мислеле) - теоријата на вишок вредност.

Друг начин на кој бугарската социологија успеала да го спаси Маркс и да биде оригинална е преку хегелијански видувања. Ова донекаде се должи на делото на Ошавков: како што вели Стефан Дончев, Ошавков „успеал да го поврзе систематскиот пристап и всушност, структурно-финкционалниот, со Хегел, со неговата Наукайа логика што е всушност систематски пристап. И тој [Ошавков] се мачел да докаже дека се надоврзува на Маркс, за да не го обвинат за веберијанизам“46. Слично, Виктор Самуилов вели дека во 1960-тите одлучил да се занимава со филозофија откако дипломирал политичка

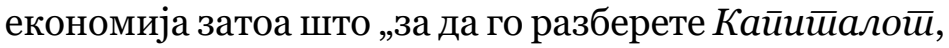
мора да ја разберете Хегеловата Логика“47. Подоцнежните претставници на бугарската социологија негувале особен и близок однос кон Хегеловата Лоәика, но сепак не секогаш за да го фалат Маркс или просто продуктивно да скршнат од партиските линии за да ги спасат своите лични и професионални простори. Како што забележа Марк Баскин за доцните 1980-ти и раните 1990-ти, додека „Живковиот ancien régime почнувал да се распаѓa, се појавил автентичен бугарски марксизам како обид да се ожи-

45 Колева, Ненкова и Тренева, Социологията през погледа, 127.

46 Ibid.,129.

47 Ibid., 186.
A more engaged and non-subversive approach can be found in the work of Mitev. In 1973 he was the scholar who, by surveying a huge archive of articles from Voprosyi filosofii, showed that the Soviet Marxist literature gradually abandoned Marx's Capital in the period 1948-55, listed as the third most cited text by both Marx and Engels, but the next two periods - 195663 and 1964-71 respectively - saw the advancement of this work on the second and then the first place of quotations. ${ }^{51}$ Mitev effectively published a contribution to the sociology of philosophy in the USSR and his data ${ }^{2}$ do suggest a correlation between the use of Capital in Soviet Marxism and a return to Lenin's materialism (which does not mean that Lenin's agenda from his Philosophical Notebooks should be read as the ignition behind the Bulgarian sociological interest in Hegel and the logic of Capital). Mitev showed that the period 19481971 saw an increase of the quotations of Marx from 4.19\% to $32.49 \%$. He specially emphasized that 1953 saw an unexpected and huge increase in quoting Capital, not leaving Stalin's death out of the equation; and that 1955 saw the increased interest in Economic-Philosophical Manuscripts of $1844 .{ }^{53}$ Bulgarian Marxism was not the subject proper for Mitev's study, i.e., he did not compare quotation trends in Bulgaria and USSR - but if we were to find a correlation between the quotation trends in

51 Petar-Emil Mitev, "Savremennoto savetsko marksovedenie," in Izsledvaniya varhu istoriyata na marksistkata filosofiya, ed. by Petar-Emil Mitev (Sofia: Nauka i izkustvo, 1973), 1415. In a paper from 2008, Mitev's student Boris Popivanov has presented data from the same journal extending it to the period 1948-2007, which reveals similar correlations between works quoted and the ideological transformations in the conjuncture. Boris Popivanov, "Aktualizatsiyata na Marks," Literaturen klub (2008), www.litclub.com/library/fil/ bpopivanov/index.html.

52 See all figures in Mitev, "Savremennoto," 16 and ff.

53 Ibid., 18-19. 
вее духот на опозицијата и на масовното движење во рамките на БСП“48. Ова не го спречило Нико Јахиел да тврди подоцна, во 1988 г., дека „нашата социологија е науката на партијата..."49, можеби не можејќи да го одвои историскиот материјализам од „социологијата“, од погрешни причини.

Покрај хегелијанското влијание, одлучувачката линија на оргиналното истражување ќе се следи поради посетата на грузискиот филозоф Мераб Мамардашвили во Бугарија во 1970-тите. Таму тој ѝ зборувал на тогаш помладата генерација, и оставил печат врз бугарската социолошка култура, оставајќи чуден социолошки прием кој полека ќе помогне да се еманципира марксистичкото учење, особено поради неговото пишување за „некласичната рационалност“ и напис за Марксовите „verwandelten formen“. Веќе имало интерес на Факултетот за филозофија за делата на Евалд Илјенков и неговата Дијалекииччка логика. Дејан Дејанов ќе го започне проектот за по-

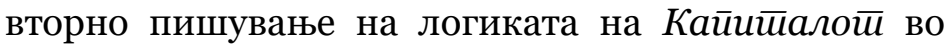
серија расфрлани написи кои се појавувале најмногу во 1990-тите; сепак одлучувачкиот момент било интелектуалното производство на она што се нарекувало „Марксов семинар“, што главно било синтеза меѓу Маркс и другите автори (Фројд, Вебер, Симел, итн.) и претставувало обид да се применува феноменолошката социологија. Дисертацијата на Делчев се чини добар пример за тоа како некој може да се занимава

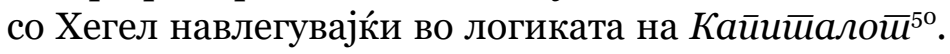

48 Mark Baskin, "Bulgaria: From Critique to Civil Society?," in The Road to Disillusion: From Critical Marxism to Postcommunism in Eastern Europe, ed. by Raymond C. Taras (Armonk, New York: M.E. Sharpe, 1992), 153.

49 Цитирано во ibid.

50 Видете „Интервю с Деян Деянов“, во Колева, Ненкова и Тренева, Социологията през погледа, 280-1; некои примери: Деян Деянов, Кольо Коев и Деян Кюранов, „Младият Маркс като критик: от журналистика към
Soviet Marxism and the Bulgarian satellite one, there might be such a correlation, even though one can hardly find a local "interpretation" of Lenin and Stalin. ${ }^{54}$

The rise of original scholarship from the 1980s out of Bulgarian sociology can be also seen as the byproduct of the first two generations trained ideologically by ASSSM, as well as philosophically, mostly at the Sofia University. Tsatsov's research leads him to conclude that professors employed at the Sofia University can be labeled revisionists. ${ }^{55}$ The aforementioned interest in the young Marx was something of a dissident activity at a time when the subject matter was no longer a scandal. ${ }^{56}$ The sociological circles discussed here are neatly networked with other disciplines, and the resulting formations were commonly called "the Seminar", which included the so-called Marx Seminar. It is now well documented and commented upon. ${ }^{57}$

54 But see for example from the same period, among a variety of texts, Tsvetan Tsanev, "Leninovata teoriya za imperializma i razvitieto na savremenniya kapitalizam," Leninizmatmarksizam na nashata epoha, Vol. 43 of Izvestiya/Nauchni trudove na AONSU pri TsK na BKP - filosofski serii (1970), 4776; and in the same volume: Sava Ganovski, "Leninizmat - nov etap v razvitieto na marksizma," 5-22.

55 Tsatsov, Dogmatitsi i revizionisti, 40.

56 Baskin calls them "in-house critics," see "Bulgaria: From Critique to Civil Society?," 153.

57 See Miglena Nikolchina, "The Seminar: Mode d'emploi. Impure Spaces in the Light of Late Totalitarianism," differences: A Journal of Feminist Cultural Studies, Vol. 13, No. 1 (2002), 96-127; the special issue devoted on "The Academic (Under)ground 1981-1989" of Piron, No. 8 (2014), ed. by Galina Goncharova, www.piron.culturecenter-su.org/ category/akademichen-underground; and Koleva, Nenkova and Treneva, Sotsiologiyata prez pogleda, 364, for a list of participants. 
Можеби терминот „автономни“ наместо „оригинални“, подобро ги опишува овие научни активности засновани врз Маркс и/преку Хегел, негувани под влијанието на Ошавков и на Стојан Михајлов.

Поангажиран и непоткопувачки пристап може да се најде во работата на Митев. Во 1973 г. тој бил истражувачот кој, прегледувајќи огромна архива на написи од Войросы философии, покажал дека советската марксистичка литература постепено го напуштила Марксовиот Кайийал во периодот од 1948 до 1955 г., наведен како трет најцитиран текст од страна на Маркс и на Енгелс, но во следните два периоди - 1956-63 и 1964-71 г. - ова дело било унапредено на второ, а потоа и на прво место по цитираност ${ }^{51}$. Митев ефективно објавил прилог за социологијата на филозофијата во СССР и неговите податоци ${ }^{52}$

теория“, Философска мисъл, No. 11 (1983), 85-94; докторатот на Красимир Делчев, Сравнителен анализ на някои диалектически моменти в глава първа на Капиталът на Маркс и Науката логика на Хегел (София: Софийски университет, 1987); како и докторатот на Деян Кюранов објавен како: От опозиция към позиция. Хегел, Фойербах, Маркс - из методологията на ХХ век (София: Наука и изкуство, 1989); Деян Деянов и Георги Каприев, „Хегеловата“ логика на Маркс“, Философска мисъл, №. 9 (1988), 66-9.

51 Петър-Емил Митев, „Съвременното съветско марксоведение“, во Изследвания върху историята на марксистката философия, съст. Петър-Емил Митев (София: Наука и изкуство, 1973), 14-15. Во есеј од 2008 г., студентот на Митев, Борис Попиванов, претставил податоци од истото списание и го проширил на периодот 1948-2007 г., што открива слични корелации меѓу цитираните дела и идеолошките трансформации во конјунктурата. Борис Попиванов, „Актуализацията на Маркс“, Литературен клуб (2008), www.litclub.com/ library/fil/bpopivanov/index.html.
A serious scholar cannot claim that there is a particularly original reception of Capital in the Bulgarian literature until 1990. The literature, in the two periods I have outlined, and with the notable exceptions of the logicians/phenomenologists and some representative of the sociology of youth, can easily fall into the label of what Koleva very succinctly calls "orthodox Marxism-based discourse, ${ }^{\circ 8}$ which applies the histmat perspective of sociology to treat issues such as forms of social development, social laws, the structure of MarxistLeninist science, all devoid of empirical data.

There were few more ways for Bulgarian scholars to develop their Marxism. One was commemorative editions. There are five significant editions in the period 1933-1987 which are commemorative for each of the decades until the 1980 s, and whose published papers are far from original research. One of the purposes of those editions was also to systematically collate bibliographies. To this period we can add two more editions which are, again, textbooks on Capital rather than research proper. ${ }^{59}$ Both are editions of ASSSM, for internal use, and are transcribed and edited lectures - which is still esoteric literature.

The latter leads us to another very important outlet for the reception of Marx's writings - the so-called "internaluse translations" carried either in university faculties or the ASSSM. I have seen and consulted copies of translations from the 1970 s onwards by "bourgeois" Western Marxists such as Fromm, Marcuse, Korsch, etc., but also by orthodox ones such as Lukács' History and Class Consciousness, done by ASSSM students and staff, and which were never published - but often they were not

58 Koleva, Sotsiologiyata kato proekt, 179.

59 Zlatko Zlatev, Kapitalat - tom 1 na Karl Marks: Lektsiya (Sofia: ASSSM, 1984); Mira Jovanovich, Kapitalat na Karl Marks - vtori i treti tom: Sbornik lektsii (Sofia: ASSSM, 1988). 16. 
навестуваат корелација помеѓу користењето на

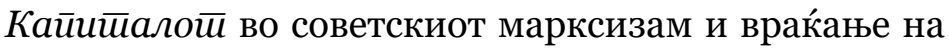
марксизмот на Ленин (што не значи дека агендата на

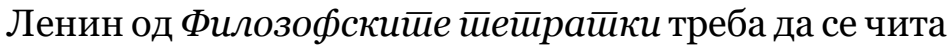
како причина за потпалување на бугарскиот опште-

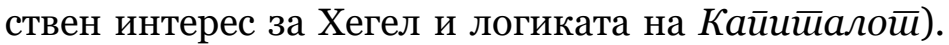
Митев покажа дека во периодот 1948-71 г. имало зголемување на цитирањето на Маркс, од 4,19 \% на 32,49 \%. Особено истакнал дека во 1953 г. имало неочекувано и огромно зголемување на цитирањето на

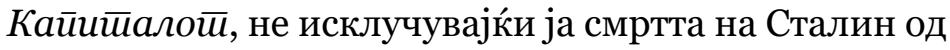
равенството; и дека во 1955 г. се зголемил интересот за Економско-филозофскийе ракойиси оg 1844 2.53. Бугарскиот марксизам не бил вистински предмет на студијата на Митев, т.е. не ги споредувал трендовите на цитирање во Бугарија и во СССР - но ако бараме корелација помеѓу трендовите во советскиот марксизам и во сателитскиот бугарски, може да има таква корелација, иако едвај може да се најде локално „толкување“ дури и на Ленин и Сталин ${ }^{54}$.

На порастот на оригиналното учење од 1980-тите од бугарската социологија може да се гледа како на нуспроизвод на првите две генерации обучувани според идеологијата на АОНОУ, како и филозофски, главно на Софискиот универзитет. Истражувањето на Цацов води до заклучок дека вработените на Софискиот универзитет може да се етикетираат главно

53 Ibid., 18-19.

54 Но видете пример од истиот период, меѓу разните текстови, Цветан Цанев, „Лениновата теория за империализма и развитието на съвременния капитализъм“, Ленинизмът-марксизъм на нашата епоха, т. 43 од Известия/Научни трудове на АОНСУ при ЦК на БКП - философски серии (1970), 47-76; и во истиот том: Сава Гановски, „Ленинизмът - нов етап в развитието на марксизма“, 5-22. meant to in the first place. ${ }^{60}$ The role of such translations was to provide something of a platform for premeditated and informed non-consent with Western Marxism. But access to such translations circulating between colleagues, which was quite exclusive, did contribute to Bulgarian Marxist scholars' knowledgeability and opening toward Marxist humanism or Althusserian antihumanism that in the 1980 s will become itself something of a platform for internal opposition, as Baskin suggests. ${ }^{61}$ The "economistic" Marx was never under attack by party-led scientific establishments once the labor theory of value was purged of the notion of surplus value, which can be seen in the unofficial interest of translations of this kind. But the economistic Marx was not the object of desire either. Hence Capital and departments of political economy were not scrutinized intensely for party loyalty the way philosophical cadre was. Political economy was already synthetically mortified.

A final way in which philosophical workers managed to experiment with ideas off the party radar was the genre of forewords. Bulgarian socialist publishing did excel in both the quality of the delivered product and its ideological vacuum. The foreword was the twoedged sword of the cultural-creative intelligentsia, at once serving to check the author's/the specialist's party loyalty and being instrumentalized for the purposes of novelty and unorthodoxy. As one writer claims, the foreword was the excuse used to defy censorship. This is true for both literary and scientific publications. In short, "the foreword has to explain why translating into Bulgarian the given work is not detrimental, and to show that the book has been published elsewhere -

60 Mineva, "On the Reception," 70, labels something along these lines as a "re-leninization of Bulgarian Marxism," in line with a return to the "philosophical Lenin."

61 He does so by analyzing the works of Zhelyu Zhelev and Blagovest Georgiev. 
како ревизионисти ${ }^{55}$. Претходно споменатиот интерес во младиот Маркс бил донекаде дисидентска активност во време кога темата веќе не се сметала за скандалозна ${ }^{56}$. Социолошките кругови за кои се дискутира тука се уредно вмрежени со други дисциплини, и за исходните формации се користел заеднички назив „семинарот“, кој го вклучувал таканаречениот „Марксов семинар“"57.

Не мислам дека сериозен познавач може да тврди дека има особено оригинален прием на Кайийалой во бугарската литература до 1990 г. Литературата во двата периода што ги наведов, и со забележливите исклучоци на логичарите/феноменолозите и некои претставници на социологијата на младите, може лесно да потпадне под етикетата на она што Колева многу концизно го нарекува „ортодоксен дискурс заснован на марксизмот“58, кој ги третира од перспектива на историскиот материјализам социолошките прашања, како формите на општествен развој, општествени закони, структурата на науката на марксизмот-ленинизмот, без емпириски податоци.

Имало уште неколку начини на кои бугарските познавачи го развивале својот марксизам. Еден бил ко-

55 Цацов, Догматици и ревизионисти, 40.

56 Баскин ги нарекува „домашни критичари“, видете "Bulgaria: From Critique to Civil Society?," 153.

57 Видете Miglena Nikolchina, "The Seminar: Mode d'emploi. Impure Spaces in the Light of Late Totalitarianism," differences: A Journal of Feminist Cultural Studies, Vol. 13, No. 1 (2002), 96-127; специјалниот број посветен на “Академичният (Under)ground 1981-1989” на Пирон, №. 8 (2014), съст. Галина Гончарова, www.piron.culturecenter-su. org/category/akademichen-underground; и Колева, Ненкова и Тренева, Социологията през погледа, 364, за список на учесници.

58 Колева, Социологията като проект, 179. preferably in the Soviet Union." ${ }^{2}$ Intellectual currents in retrieving the young Marx, for example, did not follow suit in this case, as the specialized Russian 1956 edition was not translated, so the genre is not a universal remedy. But when it comes to meeting one of the socialism's beloved genres, sci-fi, with the technological utopias of state socialism, the genre was universally important for the series "Galactica" published by the Varna press eponymically called Georgi Bakalov. Yet the main controlling mechanism of the genre has been self-censorship, and not party censorship provided by so-called "reading groups," ${ }^{63}$ as one journalist, Petko Bocharov, testifies (echoing Kyuranov's comment above.)

Finally, for lack of space I will only mention that two other avenues of research remain to be pursued are the history of reading groups between 1878 and 1923/1944 and philosophical clubs between 1944 and 1990, as well as a closer inspection of the university doctorates defended both until and after 1990 and both in and outside Bulgaria by Bulgarian-born scholars. ${ }^{64}$

\section{V.}

What exactly is the synthesis I am discussing here synthesizing? The term Soviet-Bulgarian synthesis I use is, as indicated, borrowing some of the analytical

62 Maria Velkovska, "Prochit na istoriyata: Predgovorat pri sotsializma - izvinitelna belezhka pred tsenzurata," Dnevnik, December 25, 2012, www.dnevnik.bg/ razvlechenie/2012/12/25/1966587_prochit_na_istoriiata_ predgovorut_pri_socializma_-/.

63 Ibid.

64 I have consulted the lists published on the website of the Institute of Philosophy at BAS but decided to leave out this line of research due to lack of space. 
меморативните изданија. Има пет значајни изданија во периодот од 1933-87 г. кои се комеморативни за секоја декада до 1980-тите, и чии објавени есеи се далеку од оригинално истражување. Една од целите на овие изданија било систематското средување на библиографиите. Кон тој период можеме да додадеме уште две изданија кои, повторно, се учебници за

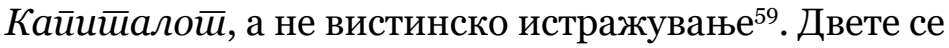
изданија на AOHOУ за интерна употреба и се транскрибирани и уредени предавања - што е сѐ уште езотерична литература.

Последното нѐ води до друг важен отвор за прием на списите на Маркс - таканаречените „преводи за интерна употреба“ кои ги имало на универзитетските факултети или на АОНОУ. Сум видел и консултирал копии на преводи од 1970-тите натаму од „буржоаски“ западни марксисти како што се Фром, Маркузе, Корш, итн., но и од ортодоксни, како Лукашовата Исйорија и класна свесй, направени од студенти и персонал на АОНОУ, кои никогаш не биле објавени - но често тоа не ни била првобитната цел ${ }^{60}$. Целта на тие преводи била да се обезбеди платформа за обмислено и свесно несогласување со западниот марксизам. Но пристапот до тие преводи кои циркулирале меѓ колегите, што било доста ексклузивно, влијаело врз знаењето и отворањето на познавачите на бугарскиот марксизам кон марксистичкиот хуманизам или Алтисеровиот антихуманизам, што во 1980-тите станал вид платформа за интерна

59 Златко Златев, Капитальт - том 1 на Карл Маркс: Лекция (София: АОНСУ, 1984); Мира Йованович, Капиталът на Карл Маркс - втори и трети том: Сборник лекции (София: АОНСУ, 1988).

60 Mineva, "On the Reception," 70, нешто слично вакво етикетира како „повторно ленинизирање на бугарскиот марксизам“, во согласност со враќањето на „филозофскиот Ленин“. might of Koleva's notion "orthodox Marxism-based discourse."65 The orthodoxy itself is not the issue. If one can claim there is no significant and systematic Bulgarian contribution to the study of Capital in a sense that will define Bulgarian science and party development by dint of officially sanctioned world-outlooks, this is due to the particular constellation of factors concocted. The synthesis of Bulgarian histmat historiography that sought, and was unable, to see a pure communist line of continuity in the pre-1944 past ${ }^{66}$ with transposing the scientific USSR infrastructure; the synthesis of Germanspeaking Russia-bred political figures and translators with the occasional anti-Russian skepticism and the Pavlovian editorial Russian orbiting; the trust in the Soviet literary expertise synthesized with the occasional sverka, the final (and perhaps only) touch of scientific autonomy in the Bulgarian MEGA edition.

Most importantly, the Soviet-Bulgarian Marxist synthesis left out of the politico-educational equation in scientific communism surplus value theory, and triumphantly assumed that its other, capitalism, was at a stand-still. And for such a synthesis between domestic scientific optimism from within and pessimism projected to the outside to work politically and domestically, it was

65 There is, of course, a certain sense of methodological nationalism in this qualification and in my own approach, but my aim here is not to de-internationalize the project of communism in its Zeitgeist and design, but rather to problematize the scientific compromises induced by the failure of globalizing communism and the consequences of pursuing the socialism-in-one-state model.

66 For example, see Stefan Minkov, "Historiography 1918-Today: Bulgaria (South East Europe)," in 1914-1918 Online.

International Encyclopedia of the First World War, ed. by Ute Daniel et al. (Berlin: Freie Universität Berlin, 2014; October 8, 2014), n.3, ff., www.encyclopedia.1914-1918-online.net/article/ historiography_1918-today_bulgaria_south_east_europe. 
опозиција, како што вели Баскин ${ }^{61}$. „Економистот“ Маркс никогаш не бил нападнат од партиски водена установа откако трудовата теорија на вредноста била исчистена од идејата за вишокот вредност, што може да се види според неофицијалната заинтересираност за таквите преводи. Но економистот Маркс не ни бил посакуваниот предмет. Затоа Кайийалой и одделите за политичка економија не биле контролирани интензивно за партиска локалност како што бил филозофскиот кадар. Политичката економија веќе била синтетички потисната.

Конечен начин на кој филозофските работници успеале да експериментираат со идеи надвор од партискиот радар бил жанрот предговори. Бугарското социјалистичко издаваштво се подобрило и во смисла на квалитет на испорачаниот производ и идеолошкиот вакуум. Предговорот бил меч со две острици за културно-креативната интелигенција, истовремено служел за проверување на лојалноста на авторот и на специјалистот и за инструментализирање за новини и за неортодоксност. Како што тврди една авторка, предговорот бил изговор против цензурата. Ова е точно и за литерарните и за научните публикации. Накусо, „предговорот мора да објасни зошто преведувањето на едно дело на бугарски не е разорно, и да се покаже дека книгата била издадена и на друго место - пожелно, во Советскиот Сојуз“62. Интелектуалните струи кои се враќаа на младиот Маркс, на пример, не го следеле овој пример, бидејќи специјализираното руско издание од 1956 г. не било

61 Тоа го прави анализирајќи ги делата на Жељу Желев и Благовест Георгиев.

62 Мария Велковска, „Прочит на историята: Предговорът при социализма - извинителна бележка пред цензурата“, Дневник, 25 декември 2012, www.dnevnik.bg/ razvlechenie/2012/12/25/1966587_prochit_na_istoriiata_ predgovorut_pri_socializma_- $/$. necessary to debilitate the very idea of capitalism's crises as a quantum leap towards fully fledged imperialism.

The synthesis I am proposing here captures the fact that the scientific appeal and use of Capital in Bulgaria was ultimately ornamental for the party lines which sought to elevate Marxism to an (allegedly) living ideology and scientific measure of all human activity, but measured only in its party dimensions, parading as they did ideologically and thus petrifying the domain of everyday life, which in turn was gradually unhinged from the ideological practices of histmat and the belief in it thereof. The relatively boring activity of studying Capital's (Bulgarian) publishing history reveals a stultifying scientific self-debilitation: the 1948 retranslation from the Russian Skvortsov-Stepanov translation (which Lenin preferred as opposed to the earlier one by G.A. Lopatin and N.F. Danielson, which Marx highly praised) highlights a political proclivity towards infrastructural scientific subservience. Beyond this ornamental ideologization, it is difficult to prove the influence of Capital as an influential pool of ideas that fed into original analysis particularly from historical and philosophical perspectives. The living battle for ideational activity and originality took place outside the critique of political economy - in biology, genetics, and gnoseology. Only few de-potentialized morsels of Marxian ideas were left to intersect - or synthesize - with those debates.

As a result, the official adoption and implementation of Marxist-Leninism as a state ideology, together with the constitutionally secured leading role of the BCP, led to a regression in the quality and independent nature of the Bulgarian reception of Marxism that was once a given during the time of Blagoev. ${ }^{67}$ This comment is neither nostalgic, not a Russophobic one, as I do not deem

67 Mineva, "On the Reception," 69. 
преведено, така што жанрот не бил универзален лек. Но што се однесува до среќавањето на еден од омилените жанри на социјализмот, научната фантастика, со технолошките утопии на државниот социјализам, жанрот бил универзално важен за сериите „Галактика“ издадени од „Варна прес“ под епонимот Ѓрѓ́ Бакалов. Сепак, главниот контролирачки механизам на жанрот била автоцензурата, а не партиската цензура, од таканаречените „читачки групи“63, како што сведочи еден новинар, Петко Бочаров (потврдувајќи го коментарот на Кјуранов даден погоре).

Конечно, поради ограничен простор, ќе споменам само две други насоки на истражување кои продолжуваат да се следат, а тоа се историјата на читачките групи од 1878 и 1923/1944 г. и филозофските клубови меѓу 1944 г. и 1990 г., како и поблиското разгледување на универзитетските докторати одбранети до и после 1990 г. од бугарски истражувачи во и надвор од Бугарија ${ }^{64}$.

V.

Што всушност синтетизира синтезата за која зборувам тука? Терминот што го користам, советско-бугарска синтеза, како што споменав, е позајмување на дел од аналитичката моќ на идејата на Колева за „ортодоксен дискурс заснован на марксизмот“65. Са-

63 Ibid.

64 Ги консултирав списоците објавени на веб-локациите на Институтот за филозофија на БАН, но се одлучив да не одам во таа насока поради недостиг на простор.

65 Секако, има одреден методолошки национализам во оваа квалификација и во мојот пристап, но мојата цел тука не е да го деинтернационализирам проектот на комунизмот во неговиот Zeitgeist и дизајн, туку да ги проблематизирам научните компромиси поттикнати од неуспехот да се the Russian/Soviet influence inherently degenerative onto Bulgarian Marxism (after all, USSR Marxism was highly original), all the more so since both Blagoev and Pavlov were strongly embraced in Russia, respectively politically and theoretically. But the fact remains that there is a correlation between the Russian re-translation and the scientific USSR isomorphism upheld in Bulgaria, resulting in the near impossibility to excavate an "interpretation." To insist on the qualifier "Bulgarian," then, is not to be nationalistic, but to avoid misleading analyses, and to open opportunities to, indeed, see an interpretation. For all of the above, in the Bulgarian case words such as "reception" and "Bulgarian" are polite misinterpretations. What we are left with is researching a bygone methodological triumphalism with the instrument of a "synthesis" that needs to discriminate terminologically in order to adjudicate theoretically. 
мата ортодоксност не е проблемот. Ако некој може да тврди дека нема значаен и сисиеемайски бугар-

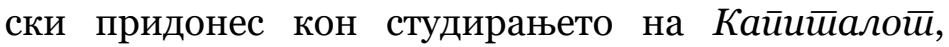
тоа ќе ги дефинира бугарската наука и развојот на партијата како официјално санкционирани светогледи, ова е поради посебната констелација на смислените фактори. Синтезата на историографијата на бугарскиот историски материјализам кој сакал (и не можел) да дојде до чисӣа комунистичка линија на континуитет во минатото пред 1944 г. ${ }^{66}$ со менување на научната инфраструктура на СССР; синтезата на политичките фигури и преведувачи кои говорат германски и се израснати во Русија со повремениот антируски скептицизам и павловското уредувачко руско орбитирање; вербата во советската литературна експертиза синтетизирана со повремена сверка, финалниот (и веројатно единствениот) допир на научна автономност во бугарското издание на MEGA.

Најважно, советско-бугарската марксистичка синтеза беше исклучена од политичко-економската равенка во теоријата за вишок вредност во научниот комунизам, и триумфално претпостави дека другото, капитализмот, е во точка на мирување. За да функционира политички и локално таква синтеза на локален научен оптимизам и песимизам проектиран нанадвор, неопходно е да се ослаби самата идеја за капиталистичката криза како квантумски скок кон целосен империјализам.

глобализира комунизмот и последиците од следење на моделот социјализам во една држава.

66 За пример, видете Stefan Minkov, "Historiography 1918-Today: Bulgaria (South East Europe),” in 1914-1918 Online. International Encyclopedia of the First World War, ed. by Ute Daniel et al. (Berlin: Freie Universität Berlin, 2014; October 8, 2014), n.3, ff., www.encyclopedia.1914-1918-online. net/article/historiography_1918-today_bulgaria_south_east_ europe. 
Синтезата која ја предлагам тука го доловува фактот дека научната привлечност и користење на

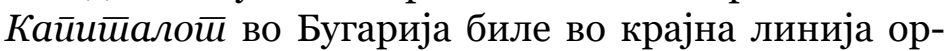
наментални за партиските линии кои сакале да го подигнат марксизмот на ниво на (наводно) жива идеологија и научна мерка за секаква човечка активност, но мерена само во своите партиски димензии, парадирајќи, како што правеле, идеолошки, и со тоа, скаменувајќи го доменот на секојдневниот живот, што од своја страна било постепено откачено од идеолошките практики на историскиот материјализам и вербата во него. Релативно здодевната активност на студирање на (бугарската) изда-

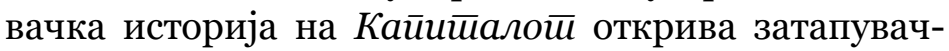
ко научно самоослабување: повторниот превод од 1948 г. од рускиот превод на Скворцов-Степанов (кој Ленин го претпочитал во однос на претходниот на Г. А. Лопатин и на Н. Ф. Даниелсон, кој пак Маркс многу го ценел) нагласува политичка склоност кон инфраструктурна научна потчинетост. Над оваа орнаментална идеологизација, тешко е да се докаже

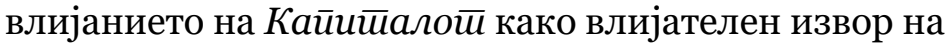
идеи што влегувале во оригинални анализи, особено од историски и филозофски перспективи. Живата битка за идејна активност и оригиналност се случувала надвор од критиката на политичката економија - во биологијата, генетиката и гносеологијата. Само неколку депотенцијализирани трошки на марксистичките идеи останале за пресекување - или синтетизирање - со тие дебати.

Како резултат на тоа, официјалното прифаќање и спроведување на марксизам-ленинизмот како државна идеологија, заедно со уставно обезбедената водечка улога на БКП, довело до намалување на квалитетот и независната природа на бугарскиот прием на марксизмот што некогаш се подразбирал во вре- 
мето на Благоев ${ }^{67}$. Овој коментар не е ниту носталгичен ниту русофобичен, бидејќи не го сметам руското/советското влијание како суштински дегенеративно за бугарскиот марксизам (најпосле, марксизмот од СССР бил крајно оригинален), а и затоа што Благоев и Павлов биле силно прифатени од Русија и политички и теоретски. Останува фактот дека има корелација меѓу рускиот повторен превод и научниот изоморфизам на СССР поддржуван од Бугарија, кој резултирал со речиси невозможност да се ископа „толкување“. Во тој случај, да се инсистира на одредницата „бугарски“ не е националистички, туку е начин да се избегне застранувачка анализа и да се отворат можности навистина да се види толкување. Заради сето споменато погоре, во бугарскиот случај, зборовите како што се „прием“ и „бугарски“ се намерни погрешни толкувања. Она што останува е истражувањето на минат методолошки триумфализам со инструментот „синтеза“ што мора да дискриминира терминолошки за да арбитрира теоретски.

Превод од англиски:

Родна Русковска

67 Mineva, "On the Reception," 69. 